\title{
Fifteen Votes for an Exit. Compromise and Responsiveness in the Brexit Process
}

\author{
Marco Giuliani
}

Brexit has been at the centre of the last two British elections and of the past legislative term. Britain's exit from the European Union was characterised by a series of parliamentary setbacks, with several government defeats, continuous rebellions and cross-party agreements made to secure control of the agenda. In the research reported in this paper, we analyzed the parliamentary Brexit process through careful examination of the three meaningful votes and twelve indicative votes held in Westminster in 2019, mapping the behaviour of each MP along two relevant dimensions. MPs' votes can be traced to the socio-economic structure of their constituencies as well as to the preferences of the latter in the 2016 Brexit referendum. Moreover, we connected these parliamentary behaviours - and thus MPs' attitudes towards compromise and responsiveness - to the gains and losses experienced during the subsequent 2019 general election. 


\section{FIFTEEN VOTES FOR AN EXIT. COMPROMiSe AND RESPONSIVENESS IN THE BREXIT ProcesS}

The Brexit legislative process generated the most hectic parliamentary phases in the recent history of UK politics. In contrast to its tradition of solidity, the executive suffered several cabinet resignations, was defeated in a series of consecutive divisions, experienced a record number of rebellions amongst its backbenchers, and lost control of the agenda.

Shortly after Theresa May lost the second meaningful vote on her European Union (Withdrawal) Act and was compelled to ask for an extension of the initial deadline of article 50 of the EU Treaty, she had to give way to the House in trying to find an alternative solution to the Brexit conundrum. The government lost a vote on the so-called Letwin amendment, named after a senior Conservative MP, by a substantial margin, which gave the legislature precedence over the executive in discussing and voting on its own motions regarding Brexit.

This interference was potentially much more invasive than previous instances of parliamentary scrutiny of the withdrawal process (Lynch et al. 2019; Thomson and Yong 2019). The prime minister, on announcing the opposition of her government to the Letwin amendment, said that parliamentary control of House business 'would set an unwelcome precedent, which would overturn the balance between our democratic institutions' (HC Deb 25 March, vol. 657, col. 24). However, three of her ministers resigned to vote in favour, together with another 27 Conservative backbenchers and a more compact opposition, with only 8 Labour MPs supporting May's position. This opened the possibility to hold a series of eight indicative votes on 27 March 2019 in the House of Commons and then another four indicative votes a few days later. 
These divisions can shed some interesting light on the political dynamics of a traditional Westminster democracy when its cornerstone, the cabinet, loses its grip on parliament and on the structure of the party government. In examining these dynamics, this article is structured as follows. First, we illustrate the content of the motions put to a division and describe in detail the results of those votes. Next, we discuss some theoretical assumptions regarding the voting behaviour of MPs in these circumstances, especially considering their responsiveness to their electorates, and derive some testable hypotheses. We then reconstruct the political space that characterized the House of Commons during the meaningful and indicative votes and test our hypotheses. In the conclusion, we verify the possible electoral consequences of these behaviours in the subsequent 2019 general election and discuss the prospects for British politics.

\section{Theory: Responsive or compromising}

Democracies are classed as such because they respond to the preferences of their citizens. Hence, we expect the voting behaviour of MPs in the House of Commons to reflect the preferences of their principals. However, there are two problems with applying that expectation directly to the parliamentary Brexit process. The first has to do with the fact that this type of vote was clearly exceptional in this institutional context, while the second concerns the multiplicity of non-overlapping principals.

Typically, the responsiveness of Westminster democracies depends on the fact that as a consequence of competition along a single dimension in a two-party system, the position of the cabinet overlaps with that of the median voter (Golder and Stramski 2010; Golder and Lloyd 2014). In this context, and due to the chain of delegation of a well enforced party-government (Strøm 2006), 'most cutting lines will split governing members against opposition members' (Hix and Noury 2015: 252). However, we have 
already mentioned that this did not happen in the situation considered, as testified by the number of rebels on both sides. ${ }^{1}$

Over the years, belonging or leaving the EU has been a highly divisive issue, both within the UK and in a wider geopolitical perspective (Hobolt 2016; Thompson 2021). It introduced a second cross-cutting cleavage in British politics that made the entire representation process extremely complicated. Moreover, it was a polarizing issue, making it harder to find a median solution. Finally, the fact that the government party was practically split over the issue (Heppell et al. 2017; Lynch and Whitaker 2017) prevented the aggregation of preferences normally produced by large parties in the context of a well-functioning party government.

The second problem has to do with the existence of multiple principals. It is not uncommon for legislators to respond to a range of potentially contrasting demands, and this usually translates into a loss of party unity (Carey 2007). However, the institutional conditions that favour such a state of affairs are not typical of the United Kingdom. Serving one's electorate, party, cabinet and country, i.e., pragmatically solving the contradiction between local and general interests, between being an ambassador of the constituency and being a representative of the nation (Burke 1999), should be typical of party government in a Westminster setting.

Nonetheless, Brexit also put this cornerstone of British politics under pressure. Contrary to Theresa May's tautological statement that 'Brexit means Brexit' (Brusenbauch Meislova 2019), many MPs from opposite sides of the House were actually confronted by a real dilemma regarding whom they should represent.

In announcing his vote against the prime minister's agreement, Sir William Cash ordered the potentially divergent principals by quoting another prime minister: 'As Churchill once said, and as I was reminded at the time of Maastricht by my constituents, 
we should put our country first, our constituency second, and our party third' (HC Deb 15 January, vol. 652, col. 1050). Another Conservative MP, Justine Greening, agreed that 'Brexit is not about party politics', so she eventually voted against her frontbenchers but recognized the problems that she faced in representing the preferences of her electorate: 'All of us are genuinely asking ourselves how we can represent our communities and do what is in the best interest of this country. [...] I represent many Remainers in my constituency who think that if we are still following so many rules, we should be around the table setting them. I also represent the many Brexiteers in my community, and they simply do not believe that this is the Brexit they felt they were voting for' (HC Deb 15 January, vol. 652, col. 1067). Labour MPs had similar problems, as acknowledged explicitly by Adrian Baley: 'I represent a constituency that voted $70 \%$ Brexit, and I am a Remainer. I do not pretend that that is a comfortable position to be in. I voted to trigger article 50 because I felt that I had to honour the referendum result, and I have been lobbied heavily to say that, as a representative, I should do what my constituency wanted' (HC Deb 15 January, vol. 652, col. 1099).

Umit and Auel (2020: 2) find confirmation of these contrasting perspectives in their analyses of legislative speeches in the aftermath of the Brexit referendum. They recognize that "where there is no consensus among their principals over a policy, MPs cannot avoid defying one or more of these principals with their vote in parliament. As a result, they become dissenters by default - irrespective of their own preferences'. As Conservative MP Simon Hoare put it, 'I do not possess the judgment of Solomon. None of us does. All I can do is assure [my constituents] that I am trying to do my best for them and for our country. I am conscious that in so doing I will not please everyone, but I do not think that that is the purpose of politics' (HC Deb 15 January, vol. 652, col. 1107). 
However, it is unlikely that MPs simply followed their idiosyncratic understanding of the Brexit issue or, better, that their position was not framed by the way in which they perceived their role as parliamentarians (Trumm et al. 2020). There are a set of factors that the literature identifies as capable of framing the way in which an MP understands her or his role as an agent (Blomgren and Rozenberg 2012; Moore 2018). We summarize them in three main categories: political, socio-economic, and institutional factors.

The most evident political factor that affects voting behaviours in a parliamentary democracy is party membership, especially when it is enforced by whipping practices. However, Theresa May's agreement was voted down in the House of Commons three times, despite the government's pressures to support it, and 'Brexit caused a wedge in party politics' (Intal and Yasseri 2019). Indicative votes usually enjoy wider margins of freedom, and the Conservative party actually did not put forward any directives on these votes, not least because it was also the most divided party in terms of motion proposals. However, opposition parties such as Labour and SNP whipped on or more informally supported some of the motions put to a division. ${ }^{2}$ Cowley and Stuart (1997) convincingly demonstrated that party divides matter even in the case of free votes, and a fortiori, we expect such divides to explain a non-marginal share of voting behaviour in the discussion of the alternatives to the government's exit agreement.

If, because of the exceptionality of the situation, parties do not always represent the primary force shaping parliamentary behaviours, constituencies can be considered the genuine principals. In fact, during the debates on the Brexit agreement, constituencies were invoked by many MPs to justify their voting decisions, despite the contradictory beliefs held by the public on the specific form that the exit should take 
(Vasilopoulou and Talving 2018). The relationship between a representative and his or her electoral district is certainly bidirectional. MPs are chosen because they somehow reflect the preferences of their districts, and once in office, they contribute to shaping those preferences, particularly in regard to individual issues or decisions. This was in fact the case with the Brexit referendum, so MPs often cited their election in a Brexit or Remain district to explain their positions on the three meaningful and twelve indicative votes. Indeed, when MPs defy a publicly expressed preference, like the referendum result, they feel compelled to explain at length the reasons for their lack of compliance (Umit and Auel 2020).

However, many electoral districts were extremely divided at the time of the referendum; approximately one-fourth of the electorate did not turn out to the polls; demographic change (an important divide in this circumstance) had already shifted the electoral base three years later, and new information as well as the details of the negotiated exit agreement could have changed voter opinions (Hobolt et al. 2020). For all these reasons, MPs might still have sought to pursue their constituencies' interests but at the same time have felt that the result of the referendum in their district could not be considered a reliable signal in this regard (Auel and Umit 2020).

Such interests are probably shaped by the underlying socio-economic structure of districts. First, socio-economic divides typically define the electoral geography of a country, especially in settings characterized by a relatively homogeneous political culture such as the UK. Second, preferences on leaving or remaining in the European Union have been convincingly connected to socio-economic cleavages (Carreras et al. 2019; Colantone and Stanig 2018; Evans and Menon 2017; Watson 2017). We can thus expect that constituencies' preferences and interests, either as expressed during the 
referendum or in relation to the deeper structure of the respective districts, affected MP voting behaviours in some way.

Personal beliefs can enter the equation when representatives feel that they have a clear point to make or a superior collective interest to serve. This condition applies perfectly to the context of the Brexit indicative votes, when the traditional shortcuts of Westminster politics proved unable to force a solution, and when the outcome clearly had to do with contrasting interpretations of the common good of the country. Political autonomy may have to do with individual characteristics, such as age, education or gender (Heppell et al. 2017), but most likely reflects some institutionally derived trait, such as parliamentary seniority, margin of election, or ministerial career (Aidt et al. 2021; Benedetto and Hix 2007). We expect these factors to have a conditional impact on voting behaviour during the indicative votes.

\section{Eight opportunities, plus another four}

Indicative votes are designed to assess whether there is any policy solution that commands a majority in parliament. They mark the failure of the cabinet to provide a viable course of action and constitute a litmus test of the parliament's capacity to reaffirm its centrality. As such, indicative votes are not frequent in a Westminster democracy like the United Kingdom, and they often do not prove particularly effective. ${ }^{3}$ Theresa May herself was understandably doubtful in this regard: 'I must confess that I am sceptical about such a process of indicative votes. When we have tried this kind of thing in the past, it has produced contradictory outcomes or no outcome at all' (HC Deb 25 March, vol. 657, col. 24).

Having obtained control of the agenda, MPs presented to the speaker 16 different motions representing a broad spectrum of alternatives, ranging from an exit 
without a deal to the revocation of article 50. Details of these proposals, together with those presented for the second round of indicative votes on April 1, are presented in Table 1.

$$
* * * \text { Table } 1 \text { here }
$$

Column 1 states the title of the proposal, followed by its first proponent and his or her party; columns 4 and 5 list the other parties and the total number of MPs who signed the motion; column 6 shows the effective number of parties that tabled the proposal, i.e. a measure of its cross-partisanship; and columns 7 and 8 give the number of MPs who voted against and in favour if the motion was put to a division.

In selecting the proposals for the parliamentary debate, speaker John Bercow balanced both their party origins and the representation of the entire range of opinions. At the same time, since the only chance of reaching a majority in support of any solution was to gain a bipartisan support, Bercow implicitly privileged motions that had been signed by MPs belonging to different parties. The mean effective number of signatory parties is 1.6 for the eight selected motions, with an average of 33 MPs who signed them, compared to just 1.3 signatories with an average of 20 advocates for the eight non-selected alternatives. The choice was even more evident in the second round of indicative votes, when all four of the selected proposals had signatories belonging to between three and six different parties, while the four that were discarded were mostly single-party motions.

Oliver Letwin anticipated the need for cross-partisanship in the debate during which the legislature managed to modify the cabinet's business motion, noting that 'one thing we will all have to do is seek compromise. We almost know that if we all vote for 
our first preference, we will never get to a majority solution' (HC Deb 25 March, vol. 657, col. 82). His suggestion was not entirely disregarded by his colleagues. Almost three-fourths of the House voted for at least two different alternatives, with more than $28 \%$ voting for four or more proposals and a record case of one MP supporting all the solutions apart from the no-deal exit and the minimalist preferential agreements option. However, this effort was not enough. All eight motions were voted down in the House of Commons on April 27, indirectly confirming the scepticism of the prime minister. Limited cross-party trust was the first cause of this failure, as shown by the data reported in Table A.1 in the online appendix.

However, as the speaker said, it was 'not utterly astonish[ing] that after one day's debate, no agreement [was] reached' (HC Deb 27 March, vol. 657, col. 462). The procedure adopted in fact favoured tactical voting, especially amongst those who backed a soft solution to the issue. Some MPs preferred not to support proposals that they probably considered better than a hard Brexit or May's deal to increase the probability of a better relative positioning of their preferred option. This was anticipated by Kenneth Clarke, who suggested before the first round of indicative votes that 'the single transferable vote is the best way to steer people to one conclusion. It will force compromise, except from those who will vote only for their first preference' (HC Deb 27 March, vol. 657, col.83). Margaret Beckett, who herself advanced one of the most supported motions, hoped to have an ordinal ballot at least in the second round, expecting that "we would first let 1,000 flowers bloom and see where we went $[\ldots]$ and that then we would seek to proceed to see whether ranking things in an order of importance made a difference' (HC Deb 27 March, vol. 657, col. 462).

However, this outcome did not materialize, and parallel independent votes prevented Parliament from obtaining anything different from the results of the first 
round of indicative votes in the second round. The cross-party proposal of a

confirmatory referendum obtained the highest amount of support, but it was the motion

of the father of the House in favour of a customs union that came closest to success,

falling short of a majority by just 3 votes. Clarke bitterly commented,

'I have got a damn sight nearer to a majority in this House than anybody else has so far [...]. Three votes is quite near. We cannot go on with everybody voting against every proposition. The difficulty is that there are people who want a people's vote who would not vote for my motion because they thought they were going to get a people's vote. There were people - the Scottish nationalists - who wanted common market 2.0, so would not vote for my motion. All of them had nothing against mine. If they continue to carry on like that, they will fail [...]. We would lose more than we would gain. Those Members should accept that they do not have a majority yet for the people's vote and vote for something that they have no objection to as a fall-back position. That is politics.' (HC Deb 27 March, vol. 657, col. 881)

Clarke addressed his criticisms mostly to the opposite side of the House, while Nick Boles, the proponent of the common market 2.0 motion, pointed to his fellow party colleagues, eventually opting to resign from the Conservative parliamentary party: 'I have given everything to an attempt to find a compromise that can take this country out of the European Union while maintaining our economic strength and our political cohesion. I accept that I have failed. I have failed chiefly because my party refuses to compromise. I regret, therefore, to announce that I can no longer sit for this party' (HC Deb 27 March, vol. 657, col. 880).

\section{The map of parliamentary behaviour}

The primary data that we used to identify patterns of parliamentary voting behaviours were the division records collected online for each MP in the House of Commons Hansard. We gathered those records for the twelve indicative votes and added records 
on the three meaningful votes held on Theresa May's agreement. ${ }^{4}$ An aye was coded with ' 1 ', a no with '-1', and abstentions or absences with zero. Assigning a nil to the latter option is common practice in the literature on parliamentary voting whenever abstention is a feasible and meaningful alternative. This was certainly the case with the indicative votes that we analysed, keeping in mind that even ministers took part in the divisions..$^{5}$

Since we wanted to explore different voting patterns, instead of the reaction to any single exit option, we proceeded by identifying the latent dimensions framing the behaviour of MPs in the fifteen divisions. Given the restricted and implicitly ordinal nature of our data, we ran a factor analysis based on a polychoric correlation matrix. Retaining the factors with eigenvalues larger than 1, we were left with just two dimensions explaining almost $90 \%$ of the variation in voting behaviour. We plotted the respective factor scores of each MP on the map reported in Figure 1, where different markers and colours are used to identify party membership. ${ }^{6}$

*** Figure 1 here

The political space of a Westminster democracy should be characterized by a single government/opposition divide (Hix and Noury 2015). The fact that we needed two dimensions to characterize the behaviour of MPs already shows how Brexit - and more generally all issues connected to the European Union (Wheatley 2019) - involved a more complex and variegated environment. We further discuss the possible reading of MPs behaviour as the effect of a single curvilinear space, together with its consequences for our overall interpretation, in the online appendix. What remains, is that several MPs on both sides joined the opposite party or, better, decided to compromise and voted in 
favour of more than one proposal, so that 'there was a visible blurring of the party line, and cross-cluster interaction (was) obvious and apparent' (Intal and Yasseri 2019: 27). From a different perspective, although some parties also whipped their MPs on selected indicative votes, there was no homogeneous party behaviour, with unusually low indices of agreement. ${ }^{7}$

The first dimension, on the $\mathrm{x}$-axis in the map, represents the different exit options and explains more than $73 \%$ of MP behaviour. On the left-hand side of the continuum are supporters of a hard Brexit, while on the right-hand side are those who prefer a softer departure.

The chart visually confirms what the agreement indices already suggested, i.e., that this dimension does not capture the typical government/opposition divide. Despite the Labour Party whipping for some of the softer options, some of its MPs appear on the left part of the map, while a substantial portion of Conservative MPs are on the opposite side. ${ }^{8}$ This interpretation is further confirmed in the appendix by Figure A.5, which shows how this dimension is also partially correlated with the degree of flexibility exhibited during the divisions. The left side of the same map is in fact occupied by those who rigidly voted against all options or exclusively for their absolute first preference, while the right side is occupied by those who chose to compromise, i.e., who voted in favour of a larger set of alternatives.

The second dimension, explaining an additional $15 \%$ of voting behaviour, can be interpreted as capturing positions for and against the cabinet and its agreement, with the former being in the upper part of the plot and the latter in the bottom part. As in the case of the previous dimension, this divide does not perfectly respect the government/opposition cleavage, although this time meaningful votes were divisive 
only for the Conservative party, as outlined by the average agreement indices in the bottom part of Table A.2 in the appendix.

In regards to the positions on the map, starting from the bottom-left part of the plot and moving clockwise, we encounter the following:

- Tory MPs close to the European Research Group, together with most DUP members and some Labour Brexiteers like Graham Stringer and Kate Hoey, all opposing May’s agreement as well as any soft exit option;

- Eurosceptics wanting to deliver Brexit following the prime minister's plan but accepting even harder options, among them several government members or opposition MPs like John Mann;

- Conservative and Labour party supporters of Theresa May's agreement like Oliver Letwin and Ian Austin, who for different reasons disregarded their respective parties' instructions and ended the legislative term as independent MPs;

- Negotiating MPs like the father of the House, Kenneth Clark, who voted in favour of 7 of the motions put forward in the twelve indicative votes and loyally supported the government's agreement but later had the whip removed by Boris Johnson;

- The bulk of Labour MPs, who opposed Theresa May and were open to a range of softer options, including a confirmative second referendum or the revocation of article 50;

- The majority of SNP MPs, together with some Liberal Democrats, who opposed Theresa May and supported a more limited range of alternatives to her agreement; 
- Conservative Remainers like Heidi Allen and Anna Soubry, who left their party to first join the Independent group and then found the new Change UK parliamentary group.

\section{Covariates and expectations}

As stated in the theoretical section, we expected to find some systematic pattern associated with the location of each MP along the two dimensions of the map. If the traditional government/opposition divide cannot explain those placements exhaustively, that does not mean that parties are irrelevant. Partisanship was a necessary control variable precisely because we also expected something else to contribute to MP behaviour.

To check for an influence of the socio-economic structure of the constituency, we referred to 2011 census data. ${ }^{9}$ The fact that our source of information dated back to five years before the Brexit referendum and eight years before the divisions that we examined was a great advantage. On the one hand, statistically speaking, these data helped avoiding any risk of backward causation. On the other hand, more substantially, they made us less susceptible to short-term explanations and allowed us to establish a link with the representation of long-lasting features of MPs' electoral districts.

We retrieved data connected to the typical political geography of the United Kingdom, considering issues - such as national identity, migration and so-called left behind groups - that have been extensively considered to be associated with Brexit and electoral behaviour (Boyle et al. 2018; Johnston et al. 2018). We considered demographic characteristics such as the population density, urban structure, and age structure of the district, focusing on the share of people aged between 15 and 24; 
identity-connected characteristics such as being born in the UK or declaring oneself to be Christian; economic characteristics such as the share of people working in the manufacturing sector, holding a routine occupation, or living in a deprived household; and educational characteristics such as the share of people with a university degree.

Our expectation was that even after we controlled for partisanship, these variables would affect MP behaviour. More specifically, we expected MPs elected in urban, younger, less deprived and comparatively more educated districts to opt for softer exit options, i.e., those located in the right-hand part of the graph with positive scores on the first dimension. Conversely, we expected MPs elected in less cosmopolitan districts, with higher shares of voters holding manufacturing and routine occupations, with larger Christian population shares, to have advocated in favour of a harder Brexit. It was less clear whether to expect any relationship with support for Theresa May's agreement, our second dimension, and we left the issue for empirical investigation.

Alternatively, the most evident expression of the specific preferences of a constituency, often mentioned in parliamentary speeches, is the district result of the Brexit referendum. Hanretty (2017) estimated the share of voters who opted for Leave in England, Scotland and Wales, remedying the fact that local counting areas did not correspond to the electoral districts; we complemented these data with the results for Northern Ireland, which are directly available at the constituency level. Our expectation was obviously that the larger the share of Leavers, the more likely an MP is to be placed on the left-hand side of the map. A slightly less precise and less demanding index is to consider simply whether the Leave option prevailed in the district, thus reducing the original share of voters to a much simpler dummy variable. 
Once again, our expectations on the relationship with the second dimension were uncertain. On the one hand, May's agreement could have been seen as the most feasible way to deliver Brexit, i.e., to fulfil the expectations of constituencies that voted to leave. On the other hand, May's solution could have been considered insufficient or the prime minister herself not entirely capable of delivering Brexit, especially if we consider her defeat in the 2017 general election.

Two conditional factors could partially mitigate the relationship posited above. The first has to do with the electoral confidence of representatives. The wider their electoral winning margins, the more they could diverge from the specific preferences of their principals, the constituencies, on the Brexit issue. The second factor is related to MP seniority. Senior representatives are no less tied to their constituencies, but their authority and long-lasting relationship with the electorate could grant them a greater degree of freedom, so that we might expect them to have both more extreme or more moderate positions than those predicted by district preferences.

\section{Results and some further consequences}

In Figure 2, we report the standardized coefficients and 95\% confidence intervals for the aforementioned series of regression models, all having the party membership of each MP as a control variable and robust standard errors. ${ }^{10}$ On the left-hand side, we evaluate the determinants of the scores on the first dimension of the previous map, while on the right-hand side, we compare the corresponding values for the second dimension.

\footnotetext{
$* * *$ Figure 2 here
} 
Most of our expectations related to the first dimension were corroborated. Our data confirmed the contrast between younger, educated and relatively more affluent constituencies, on the one hand, and - to use the now popular image - left-behind and more traditional districts shaken by globalization on the other (Colantone and Stanig 2018). These results confirm the significance of the integration/demarcation conflict structure, with its twofold economic and cultural logic (Grande and Kriesi 2012). Census variables do not have the same bearing on the scores in the second dimension: several coefficients cannot reject the null effect hypothesis, although the socioeconomic structure of the district, best represented by the share of manufacturing workers and holders of routine occupations, does seem to be associated with MPs supporting the effort of the prime minister to deliver Brexit.

Highly significant, but only for the first dimension, is the more proximate effect of the referendum results on MP behaviour. Interestingly, it is not just the black-orwhite impact of a Leave or Remain result that matters but also the degree of the respective victories that has a proportionate influence on the more or less radical positions advocated by constituencies' representatives. The confounding effect of electoral uncertainty and parliamentary seniority was evaluated in two different ways: by conducting a heteroskedastic regression, with the variation around the mean modelled by the electoral margin and the year of an MP's first election, and by interacting the two factors with the share of Leave voters. We report all the model results in the appendix, although what we found confirms that senior representatives enjoy larger behavioural freedom; i.e., their behaviour is more poorly explained by their constituents' Brexit preferences, the influence of which, at the same time, decreases and eventually stops being relevant as the margin of an MP's electoral win in the preceding 2017 election increases (see Figure 3). 
*** Figure 3 here

To come full circle, we needed to complete the final step of our analysis. Since the 2019 general election was called because of and de facto closed the Brexit saga, what were its consequences for the positions advocated during the fifteen divisions under consideration (Axe-Browne and Hansen 2021)? The election was an undisputed success for Boris Johnson's strategy and a landslide victory for the Conservative party, with 'Brexit fundamentally reshap[ing] the nature of electoral competition' (Prosser 2021: 10). It also demonstrated the diverse capacities of the two major parties to adapt to the changing post-referendum political environment (Hayton 2021). Our data permitted a closer look at this issue from the perspective of the relationship between each representative and his or her constituency.

Since we confirmed that the behaviour of MPs was on average linked to the exit preferences of their constituencies, were there any consequences for having somehow betrayed them or for having taken a more compromising attitude during the indicative votes? While the former question can also be answered simultaneously for all legislators, testing the hypothetical impact of non-responsiveness on support for the 2017 district incumbent, the effect of compromising behaviour needs to be checked separately for each party. Because only two parliamentary groups satisfied the minimum number of observations required for a statistical analysis, we restricted this latter investigation to the two major parties.

Compromise was effectively captured by the first dimension of the map of MPs behaviour, whereas we measured the lack of responsiveness by taking advantage of the residuals of the regression model plotted in figure 3. The larger the residuals, the more 
the constituency's preferences were 'betrayed' by the representative. We then regress the 2019 district results of the incumbents on our measures of responsiveness and compromise using a set of control variables: the estimated proportion of Leave votes, to keep constant the original exit preferences of each constituency; the electoral margin in the previous election, to capture any strategic incentives for MPs in districts with slim majorities, and the change in turnout at the district level, to evaluate the potentially mobilizing/demobilizing effect on the electorate of the lack of responsiveness or willingness to compromise displayed by MP behaviour (Cutts et al. 2020).

\section{*** Table 2 here}

According to model 1 presented in Table 2, a lack of responsiveness on Brexit was systematically sanctioned amongst all MPs in the 2019 general election. A set of postestimation diagnostic confirm the absence of omitted variables and the correctness of the model specification.

The reduced statistical power probably limited the statistical significance of the responsiveness coefficient once the analyses weres limited to the subsets of MPS belonging to each of the two major parties, but still the effect remained significant also in model 2 and 3. The negative effect of the 'betrayal' was counterbalanced by the Leave preferences in the Conservative districts, while it was reinforced by that same factor in Labour constituencies. ${ }^{11}$ Interestingly, all other things being equal, increasing turnout depressed support for the incumbent party in Conservative districts while boosting it in Labour districts, whereas electoral uncertainty played a role only in the former ones. 
Regarding the cost of compromise, models 4 and 5, the party differences are more striking. For a Labour MP, to embrace several soft solutions was to remain close to the party line, even though not all of the options were whipped by Jeremy Corbyn, so that voting in favour of multiple exit options was eventually positively welcomed by the respective constituencies. The opposite occurred for Conservative MPs, for whom supporting multiple softer exit options proved electorally detrimental (AlexandreCollier 2020). ${ }^{12}$ Having a representative who favoured compromise was generally more costly for the Conservative than for the Labour party also when the party was a minority in the district. No matter what position a Labour incumbent took in parliament on the Brexit issue, the Conservative challenger was not favoured in the general election, while the same cannot be said of Labour challengers in Conservative districts, who were instead favoured when the Conservative incumbent was more inclined to compromise.

\section{Conclusion}

The Brexit parliamentary process, with its government defeats, back-bencher rebellions and cross-party bargaining, has been rather extraordinary for a Westminster democracy. We examined in detail fifteen EU divisions - the three meaningful votes on Theresa May's exit agreement plus twelve indicative votes on alternative parliamentary exit proposals - that best represented the unusual political dynamics of the period. The behaviour and voting choices of MPs were not random, dictated by party discipline or by personal beliefs. They were instead closely connected to some distal structural features and to the more proximate preferences of their constituencies on EU membership expressed during the Brexit referendum. The choices were further moderated or conditioned by the seniority of the representatives and by their election in more or less safe districts. Finally, we demonstrated how the positions that MPs 
advocated were connected to the success/loss experienced by their party in the subsequent general election.

The fact that political divides did not follow the usual government/opposition lines throughout these events was certainly not indicative of a weakness in the British political system. In fact, the good news is that the legislators mostly remained responsive to their constituencies even when they decided not to follow the party whip and compromise with MPs from the other side of the House. On average, they remained faithful to their main electoral principals, trying to accommodate their preferences within a party government framework, something that confirms previous findings by Hanretty et al. (2017).

The fact that MPs refrained from following the norms of the usual adversarial disciplined politics does not entail that they massively adopted the more cooperative style that has sometimes been invoked as a solution to the Brexit stalemate. The failure of the twelve indicative votes clearly indicates a lack of familiarity with those cooperative dynamics, starting from the very choice of voting procedures. It is probably fair to say that if the parties had more experience with consensual practices, i.e., had they been more used to compromising to avoid the worst outcomes, the story might have had a different outcome.

There is no obvious counterfactual, and it is still unclear if the unusual period will have political aftershocks or if Johnson's landslide victory will complete the restoration of more traditional Westminster dynamics (AA 2021; Baldini et al. 2021). The swift parliamentary approval of the exit agreement immediately at the beginning of the new legislative term seems consistent with the second hypothesis, and yet the fact that MPs' behaviour can be explained by structural features of their constituencies measured almost a decade earlier suggests a more cautious position may be warranted. 
A more cooperative style may even be useful for a resolute prime minister like Boris Johnson. Ultimately, in December 2020, the Gordian knot of the deal between the United Kingdom and its former EU counterparts was not cut unilaterally, as the Prime Minister had sought to do internally one year prior by calling a snap election. It required the sort of give-and-take and compromising attitude that will certainly also come in handy in the future in the many domestic and global negotiations that will be crucial for a sovereign UK.

${ }^{1}$ Hix and Noury (2015) recognize that 'non-whipped' votes could be the exception to this rule. In fact, while the government whipped against the Letwin amendment, which allowed the indicative votes, it did not on the divisions themselves, although they were clearly alternatives to the original exit agreement proposed by the prime minister..

${ }^{2}$ Voting on party lines was further complicated because most of the motions included signatories on both sides of the government/opposition divide.

${ }^{3}$ One famous example is the debate held in the Commons in February 2003 on reform of the House of Lords: several motions - their proposals ranging from a fully appointed to a fully elected second chamber to full abolition - were voted on separately, but to everyone's surprise, none of them passed (McLean et al. 2003).

${ }^{4}$ We also experimented with all 84 divisions held on Brexit-related issues during the year 2019 under both Theresa May and Boris Johnson as prime ministers. Following the same aggregating procedure explained in the text produced very similar results, with two main dimensions explaining most of the variation and returning a similar configuration of the map, the principal difference being a wider spread of the positions along the first dimension. The list with all the divisions and the corresponding map of MPs are reported in the online appendix. 
${ }^{5}$ It should be further remembered that MPs voted using a single ballot paper on which all options were listed, so that abstaining on some of the alternatives was a deliberate choice. Whether that choice signals indifference towards the alternative or is the result of tactical considerations does not affect our analysis of the political space.

${ }^{6}$ For descriptive purposes, in the online appendix, we include three different versions of the same map. The first one displays markers reporting belonging to the cabinet/government and the names of some prominent MPs; the second shows the UK country in which MPs were elected; and the third one reports the number of ayes in the twelve indicative divisions.

${ }^{7}$ The index of agreement measures the degree of voting cohesion amongst the members of a parliamentary group and ranges from 0 to 1 . It takes into account not only the ayes and noes, like the Rice index, but also the decision not to vote. The formula of the index, together with its application to the 12 indicative votes, is reported in Table A.2 in the appendix.

${ }^{8}$ Cabinet members were requested to abstain on indicative votes. For this reason, and differently from other government ministers, their position overlaps with that of prime minister Theresa May at the centre of the plot, tilted only slightly to the left due to the three meaningful votes that contributed to their location in the map.

${ }^{9}$ Census data at the constituency level, together with some past electoral results, were retrieved from Pippa Norris's website at https://www.pippanorris.com/data. Because of some discrepancies in the questions asked in England, Wales, Scotland and Northern Ireland, and in spite of our effort to complement and reconstruct comparable data, the number of observations may vary across variables.

${ }^{10}$ For ease of representation we have standardized the coefficients following Gelman (2008), while the raw coefficients are included in the online appendix. Due to the overlap of their explanatory potential we have not run a fully saturated model to avoid biased results. At the same time, each variable illuminates partially different aspects of the relationship between the electoral district and its representative's behaviour.

${ }^{11}$ As is better analysed in the online appendix, districts that combined Leave votes with Conservative incumbents had the most reactive electorates. 
${ }^{12}$ Some Tories, like Oliver Letwin and Kenneth Clarke, who were expelled from the parliamentary group in September 2019 for having favoured a bill preventing a no-deal exit, and Heidi Allen, who crossed the floor even before those events, decided not to stand in the 2019 election. However, their substitutes, presumably more intransigent and loyal to Boris Johnson than their predecessors, suffered more severe vote drains than in similarly compromising Conservative-led.

\section{References}

Aidt T et al. (2021) The Meaningful Votes: Voting on Brexit in the British House of Commons. Public Choice 186(3-4), 587-617.

Alexandre-Collier A (2020) From Rebellion to Extinction: Where have all the Tory Remainer MPs Gone? The Political Quarterly 91(1), 24-30.

Auel K and Umit R (2020) Who's the Boss? An analysis of the vote on the 'European Union (Notice of Withdrawal) Bill' in the House of Commons. Journal of Contemporary European Studies doi: 10.1080/14782804.2020.1815679.

Axe-Browne A and Hansen ME (2021) Still dividing the electorate? Brexit and voter evaluation of candidates. Journal of Elections, Public Opinion and Parties 31(2), 220-242.

Baldini G et al. (2021) Back to the Westminster model? The Brexit process and the UK political system. International Political Science Review doi: $10.1177 / 0192512120967375$.

Benedetto G and Hix S (2007) The Rejected, the Ejected, and the Dejected: Explaining Government Rebels in the 2001-2005 British House of Commons. Comparative Political Studies 40(7), 755-781.

Blomgren M and Rozenberg O (eds.) (2012) Parliamentary Roles in Modern Legislatures. London: Routledge.

Boyle M et al. (2018) Introducing 'Brexit Geographies': five provocations. Space and Polity 22(2), 97-110.

Brusenbauch Meislova M (2019) Brexit Means Brexit - or Does It? The Legacy of Theresa May's Discursive Treatment of Brexit. The Political Quarterly 90, 681689.

Burke E (1999) Select Works of Edmund Burke, vol. 4 [1774]. Indianapolis: Liberty Fund.

Carey JM (2007) Competing Principals, Political Institutions, and Party Unity in Legislative Voting. American Journal of Political Science 51(1), 92-107. 
Carreras M et al. (2019) Long-Term Economic Distress, Cultural Backlash, and Support for Brexit. Comparative Political Studies 52(9), 1396-1424.

Colantone I and Stanig P (2018) Global Competition and Brexit. American Political Science Review 112(2), 201-218.

Cowley P and Stuart M (1997) Sodomy, Slaughter, Sunday Shopping and Seatbelts. Free Votes in the House of Commons, 1979 to 1996. Party Politics 3(1), 119130.

Cutts D et al. (2020) Brexit, the 2019 General Election and the Realignment of British Politics. The Political Quarterly 91(1), 8-23.

Evans G and Menon A (2017) Brexit and British Politics. Cambridge: Polity Press.

Gelman A (2008) Scaling regression inputs by dividing by two standard deviations. Statistics in Medicine 27(15), 2865-73.

Golder M and Stramski J (2010) Ideological Congruence and Electoral Institutions. American Journal of Political Science 54(1), 90-106.

Golder M and Lloyd G (2014) Re-evaluating the relationship between electoral rules and ideological congruence. European Journal of Political Research 53(1), 200212.

Grande E and Kriesi $\mathbf{H}$ (2012) The transformative power of globalization and the structure of political conflict in Western Europe, In Kriesi H, et al. (eds.), Political Conflict in Western Europe. Cambridge: Cambridge University Press, pp. 3-35.

Hanretty C (2017) Areal interpolation and the UK's referendum on EU membership. Journal of Elections, Public Opinion and Parties 27(4), 466-483.

Hanretty C et al. (2017) Dyadic Representation in a Westminster System. Legislative Studies Quarterly 42(2), 235-267.

Hayton R (2021) Brexit and party change: The Conservatives and Labour at Westminster. International Political Science Review doi: 10.1177/01925121211003787.

Heppell T et al. (2017) The United Kingdom Referendum on European Union Membership: The Voting of Conservative Parliamentarians. JCMS: Journal of Common Market Studies 55(4), 762-778.

Hix S and Noury A (2015) Government-Opposition or Left-Right? The Institutional Determinants of Voting in Legislatures. Political Science Research and Methods 4(2), 249-273.

Hobolt SB (2016) The Brexit vote: a divided nation, a divided continent. Journal of European Public Policy 23(9), 1259-1277.

Hobolt SB et al. (2020) Policy Preferences and Policy Legitimacy After Referendums: Evidence from the Brexit Negotiations. Political Behavior doi: 10.1007/s11109020-09639-w.

Intal C and Yasseri T (2019) 'Dissent and Rebellion in the House of Commons: A Social Network Analysis of Brexit-Related Divisions in the 57th Parliament', (doi: 1908.08859v1).

Johnston R et al. (2018) Geographies of Brexit and its aftermath: voting in England at the 2016 referendum and the 2017 general election. Space and Polity 22(2), 162187.

Lynch P and Whitaker R (2017) All Brexiteers now? Brexit, the Conservatives and party change. British Politics 13(1), 31-47.

Lynch P et al. (2019) Brexit and the UK parliament: Challenges and Opportunities, In Christiansen T and Fromage D (eds.), Brexit and democracy. The Role of 
Parliaments in the Uk and the European Union. Basingstoke: Palgrave, pp. 5179.

McLean I et al. (2003) None of the Above: The UK House of Commons Votes on Reforming the House of Lords, February 2003. The Political Quarterly 74(3), 298-310.

Moore L (2018) Policy, Office and Votes: Conservative MPs and the Brexit Referendum. Parliamentary Affairs 71(1), 1-27.

Prosser C (2021) The end of the EU affair: the UK general election of 2019. West European Politics 44(2), 450-461.

Strøm K (2006) Parliamentary Democracy and Delegation, In Strøm K, et al. (eds.), Delegation and Accountability in Parliamentary Democracies. Oxford: Oxford University Press, pp. 55-106.

Thompson H (2021) The European Geopolitical Space and the Long Path to Brexit. Government and Opposition doi: 10.1017/gov.2021.1.

Thomson L and Yong B (2019) What Do We Mean by Parliamentary Scrutiny of Brexit? A View from the House of Commons, In Christiansen T and Fromage D (eds.), Brexit and democracy. The Role of Parliaments in the Uk and the European Union. Basingstoke: Palgrave, pp. 29-49.

Trumm S et al. (2020) The 2016 EU Referendum: Explaining Support for Brexit Among Would-Be British MPs. Political Studies 68(4), 819-836.

Umit R and Auel K (2020) Divergent preferences and legislative speeches on Brexit. Journal of Elections, Public Opinion and Parties 30(2), 202-220.

Vasilopoulou $\mathbf{S}$ and Talving L (2018) British public opinion on Brexit: controversies and contradictions. European Political Science 18(1), 134-142.

Watson M (2017) Brexit, the left behind and the let down: the political abstraction of 'the economy' and the UK's EU referendum. British Politics 13(1), 17-30.

Wheatley J (2019) The Changing Shape of Politics. Rethinking Left and Right in a New Britain. London: Palgrave. 


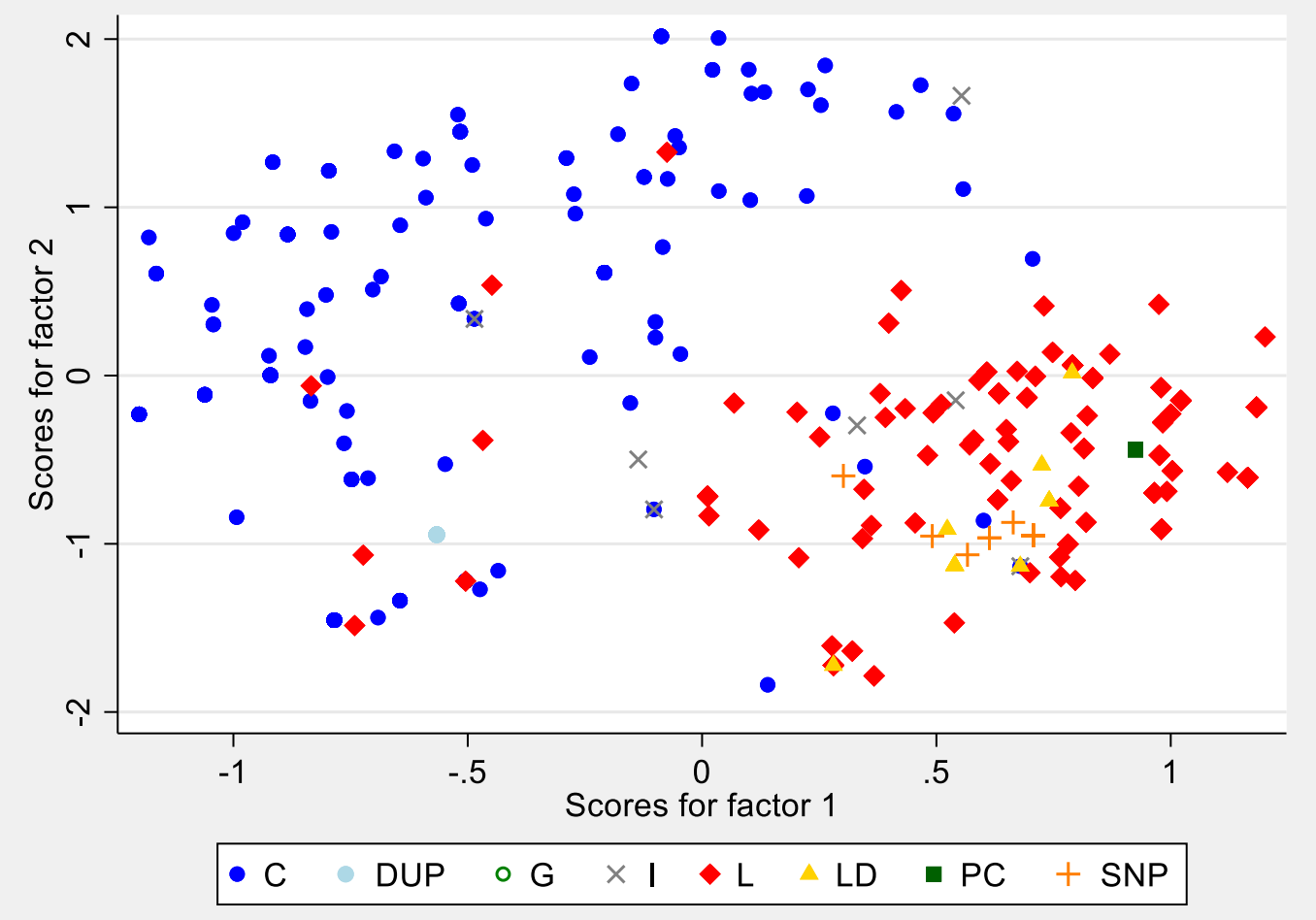

Figure 1. Map of MPs on indicative and meaningful votes 


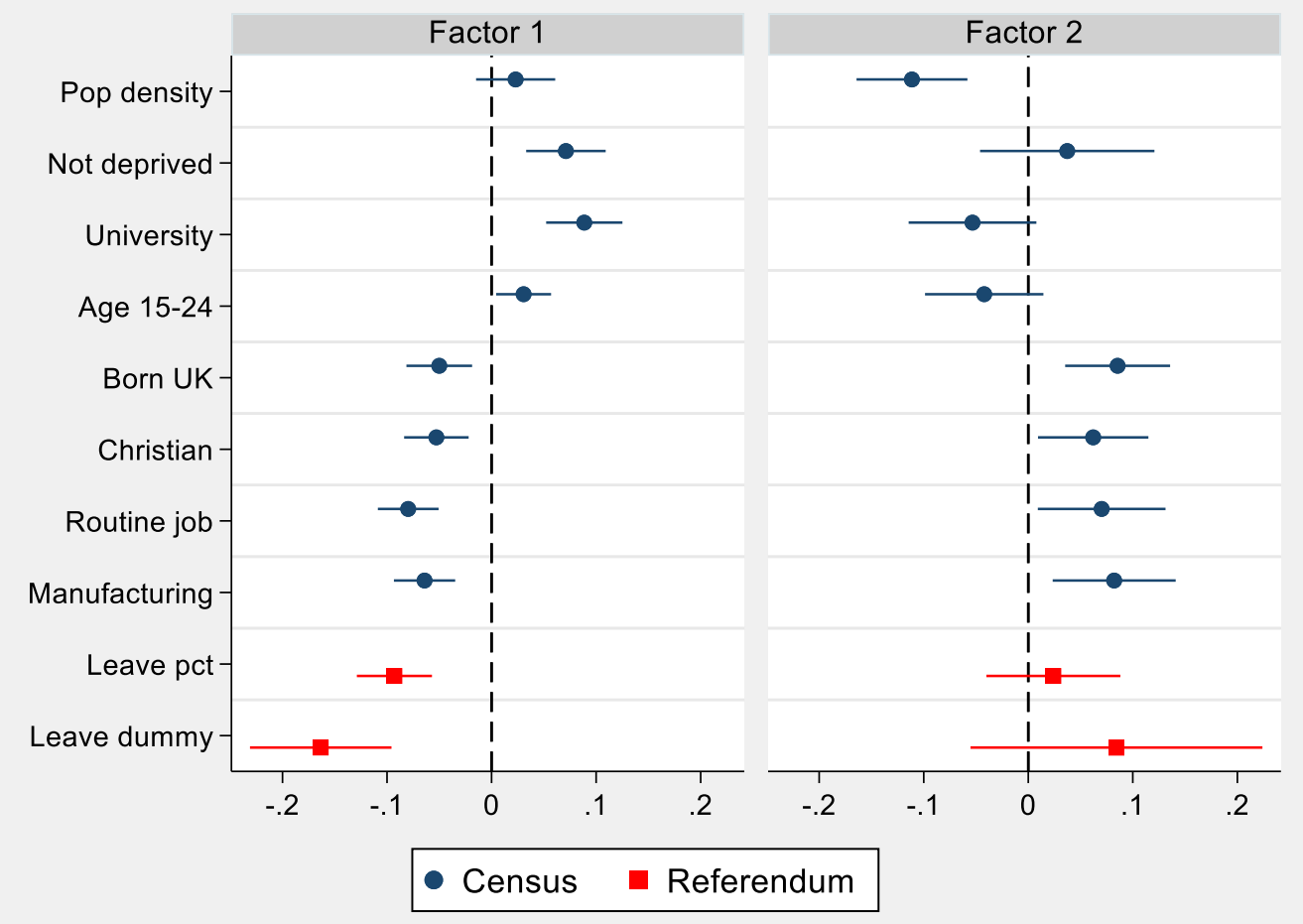

Figure 2. Regression coefficients of Census and Referendum data with 95\% confidence intervals

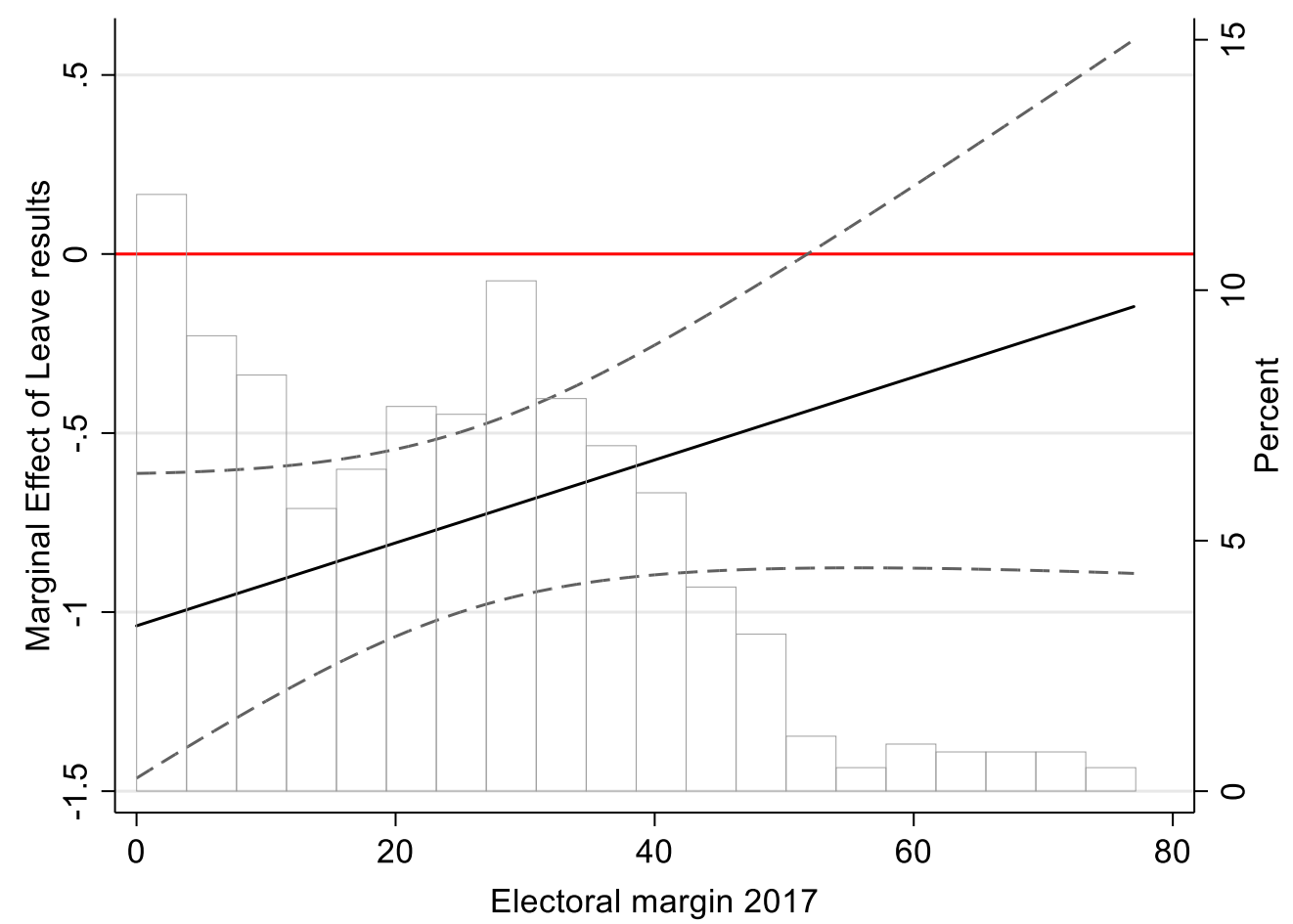


Figure 3. Marginal impact of the share of Leave votes on the MPs' scores on the first dimension at different degree of electoral certainty (winning margin in 2017), with 95\% confidence intervals

Table 1. Motions tabled for the first and second round of indicative votes

\begin{tabular}{|c|c|c|c|c|c|c|c|}
\hline MOTION & MP & PARTY & OTHER PARTIES & $\mathbf{N}$ & ENP & NOES & AYES \\
\hline A. Constitutional and accountable government & Cash W. & Con & & 32 & 1.0 & & \\
\hline B. No deal & Baron J. & Con & & 4 & 1.0 & 400 & 160 \\
\hline C. Unilateral right of exit from backstop & Baron J. & Con & & 6 & 1.0 & & \\
\hline D. Common market 2.0 & Boles N. & Con & Lab - LD & 35 & 2.0 & 283 & 188 \\
\hline E. Respect the referendum result & Quince W. & Con & DUP - Lab & 94 & 1.2 & & \\
\hline F. Participation in a customs union & Snell G. & $\mathrm{Lab}$ & & 11 & 1.0 & & \\
\hline G. Revocation instead of no deal & $\begin{array}{l}\text { MacNeil } \\
\text { A. }\end{array}$ & SNP & Con - Lab - PC & 28 & 2.8 & & \\
\hline H. EFTA and EEA & $\begin{array}{l}\text { Eustice G. } \\
\text { Blackford }\end{array}$ & Con & & 15 & 1.0 & 377 & 65 \\
\hline I. Consent of devolved institutions & I. & SNP & & 34 & 1.0 & & \\
\hline J. Customs union & Clarke K. & Con & Lab & 20 & 1.7 & 272 & 264 \\
\hline K. Labour's alternative plan & Corbyn J. & Lab & & 15 & 1.0 & 307 & 237 \\
\hline L. Revocation to avoid no deal & Cherry J. & SNP & Con - Lab - LD - PC & 38 & 3.7 & 293 & 184 \\
\hline M. Confirmatory public vote & Beckett M. & Lab & $\begin{array}{c}\text { Con - Green - LD - PC - } \\
\text { SNP }\end{array}$ & 118 & 1.7 & 295 & 268 \\
\hline N. Malthouse compromise plan A & Morgan N. & Con & DUP - Lab & 11 & 1.5 & & \\
\hline
\end{tabular}




\begin{tabular}{|c|c|c|c|c|c|c|c|}
\hline O. Contingent preferential arrangements & Fysh M. & Con & & 18 & 1.0 & 422 & 139 \\
\hline P. Contingent reciprocal arrangements & Fysh M. & Con & & 20 & 1.0 & & \\
\hline A2. Unilateral right of exit from backstop & Baron $\mathrm{J}$. & Con & & 16 & 1.0 & & \\
\hline $\begin{array}{l}\text { B2. No deal in the absence of a Withdrawal } \\
\text { Agreement }\end{array}$ & Baron J. & Con & & 10 & 1.0 & & \\
\hline C2. Customs Union & Clarke K. & Con & Lab - LD & 43 & 1.5 & 276 & 273 \\
\hline D2. Common Market 2.0 & Boles N. & Con & Lab - LD - PC - SNP & 38 & 2.3 & 282 & 261 \\
\hline E2. Confirmatory public vote & Kyle P. & Lab & $\begin{array}{c}\text { Con - Green - LD - PC - } \\
\text { SNP }\end{array}$ & 103 & 1.7 & 292 & 280 \\
\hline F2. Public vote to prevent no deal & Jones G. & $\mathrm{Lab}$ & Con & 2 & 2.0 & & \\
\hline G2. Parliamentary Supremacy & Cherry J. & SNP & $\begin{array}{c}\text { Con - Green - Lab - LD - } \\
\text { PC }\end{array}$ & 68 & 2.8 & 292 & 191 \\
\hline H. EFTA and EEA & Eustice G. & Con & & 16 & 1.0 & & \\
\hline
\end{tabular}

Note: The bold character is used for motions that were put to a division 
Table 2. The electoral costs of non-responsiveness and compromise

\begin{tabular}{|c|c|c|c|c|c|}
\hline & $\begin{array}{l}(1) \\
\text { Delta } \\
\text { party } \\
\text { votes } \\
\end{array}$ & $\begin{array}{c}(2) \\
\text { Delta } \\
\text { Conservative } \\
\text { votes } \\
\end{array}$ & $\begin{array}{c}(3) \\
\text { Delta } \\
\text { Labour } \\
\text { votes } \\
\end{array}$ & $\begin{array}{c}(4) \\
\text { Delta } \\
\text { Conservative } \\
\text { votes } \\
\end{array}$ & $\begin{array}{c}(5) \\
\text { Delta } \\
\text { Labour } \\
\text { votes } \\
\end{array}$ \\
\hline Non-responsiveness & $\begin{array}{c}-4.57 * * * \\
(1.06)\end{array}$ & $\begin{array}{l}-0.90^{*} \\
(0.47)\end{array}$ & $\begin{array}{l}-2.27 * \\
(1.22)\end{array}$ & & \\
\hline First dimension & & & & $\begin{array}{c}-0.60 * * \\
(0.27)\end{array}$ & $\begin{array}{c}2.23 * * * \\
(0.78)\end{array}$ \\
\hline Leave vote & $\begin{array}{l}-2.67 \\
(2.65)\end{array}$ & $\begin{array}{c}43.57 * * * \\
(1.86)\end{array}$ & $\begin{array}{c}-24.98 * * * \\
(2.48)\end{array}$ & $\begin{array}{c}43.60 * * * \\
(1.80)\end{array}$ & $\begin{array}{c}-23.37 * * * \\
(2.54)\end{array}$ \\
\hline Margin 2017 & $\begin{array}{c}-0.03^{* *} \\
(0.01)\end{array}$ & $\begin{array}{c}-0.14 * * * \\
(0.01)\end{array}$ & $\begin{array}{l}-0.02 \\
(0.02)\end{array}$ & $\begin{array}{c}-0.14 * * * \\
(0.01)\end{array}$ & $\begin{array}{l}-0.02 \\
(0.02)\end{array}$ \\
\hline Change turnout & $\begin{array}{l}-0.02 \\
(0.22)\end{array}$ & $\begin{array}{c}-0.22 * * \\
(0.10)\end{array}$ & $\begin{array}{l}0.25 * * \\
(0.10)\end{array}$ & $\begin{array}{c}-0.21 * * \\
(0.10)\end{array}$ & $\begin{array}{l}0.25^{* *} \\
(0.10)\end{array}$ \\
\hline Party dummies & $\checkmark$ & & & & \\
\hline Constant & $\begin{array}{c}5.59 * * * \\
(1.56)\end{array}$ & $\begin{array}{c}-18.72 * * * \\
(1.06)\end{array}$ & $\begin{array}{c}5.60 * * * \\
(1.51)\end{array}$ & $\begin{array}{c}-19.39 * * * \\
(0.97)\end{array}$ & $\begin{array}{c}2.42 \\
(1.79)\end{array}$ \\
\hline $\begin{array}{l}\text { Observations } \\
\text { R-squared }\end{array}$ & $\begin{array}{r}634 \\
0.62 \\
\end{array}$ & $\begin{array}{r}316 \\
0.81\end{array}$ & $\begin{array}{l}254 \\
0.43 \\
\end{array}$ & $\begin{array}{r}316 \\
0.81\end{array}$ & $\begin{array}{l}254 \\
0.44\end{array}$ \\
\hline
\end{tabular}
Robust standard errors in parentheses; *** $\mathrm{p}<0.01, * * \mathrm{p}<0.05, * \mathrm{p}<0.1$ 


\section{Online Appendix}

\section{Fifteen Votes for an Exit.}

\section{Compromise and Responsiveness in the Brexit Process}

\section{Contents}

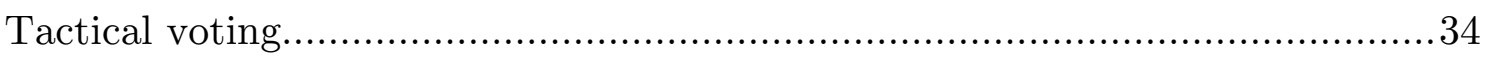

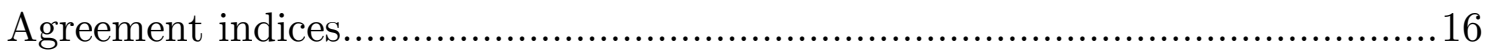

Maps and dimensions............................................................... 17

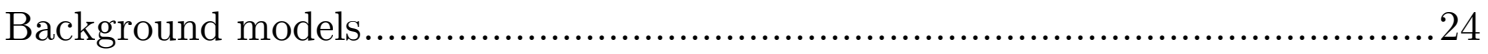

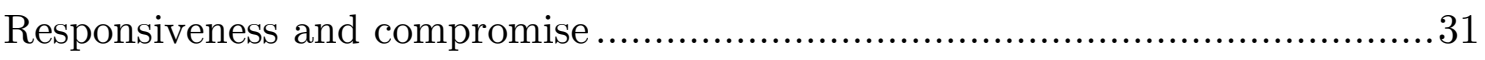

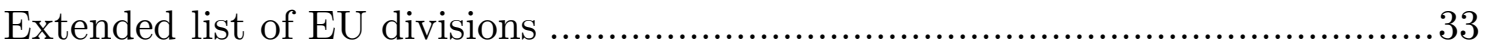

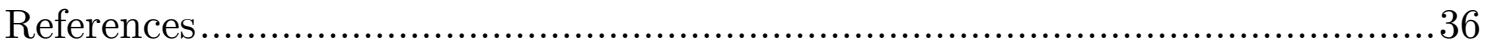




\section{Tactical voting}

In the article, we reported that Kenneth Clarke suspected that tactical voting was an obstacle to the success of his proposal of a Customs Union. We can check Clarke's idea more in detail with the data reported in Figure A. 1, where we have cross-tabulated the vote expressed on his motion with the one proposing a Confirmatory referendum. Both were defeated with similar results. 192 MPs (green cell in the left panel) voted in favour of both motions, whereas 247 opposed both of them. 

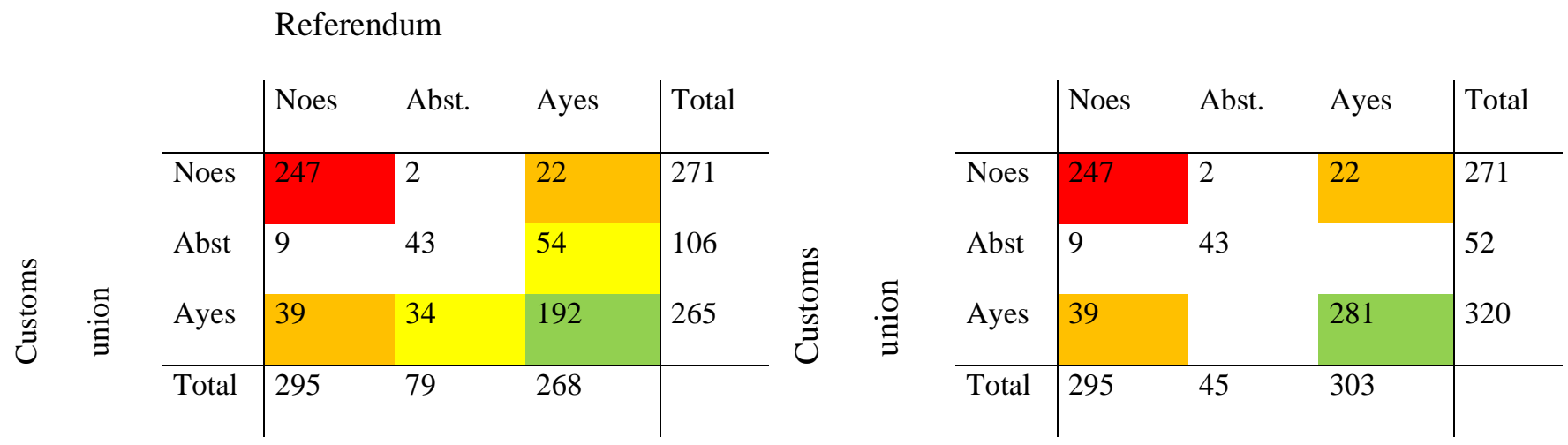

Referendum

Fig. A.1 Actual and hypothetical votes on Customs Union and Confirmatory referendum

The suspicion is that there were some tactical abstentions (yellow), or even opposition (orange). Excluding those who abstained on both motions (who may have been absent, or not convinced at all), and reshuffling those potential tactical absentees we obtain the hypothetical results presented in the right-hand panel. This time, both motions are able to move a majority, and Clarke's proposal even with a clear advantage of almost 50 votes against its opponents. Politically speaking, since the Customs Union motion is median on the second dimension, it is more probable that there were tactical abstentions damaging it, compared to those damaging the Confirmatory referendum option. 

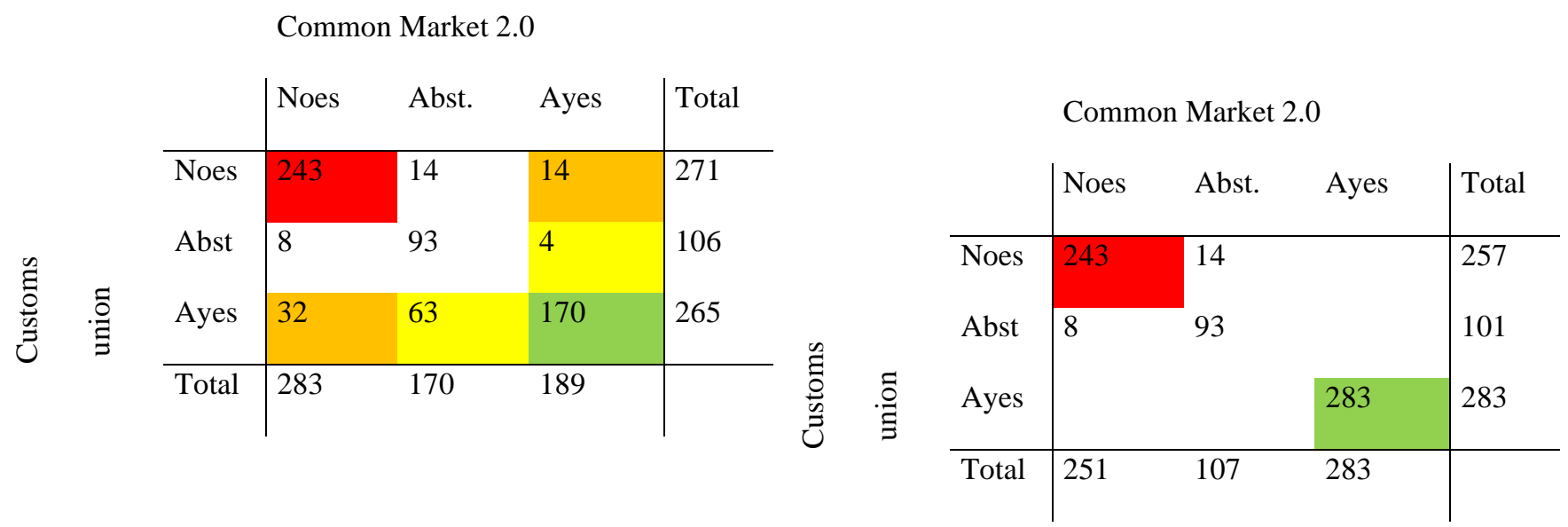

Fig. A.2 Actual and hypothetical votes on Customs Union and Common Market 2.0

In figure A.2 we check the same idea by cross-tabulating the votes on the Customs Union with that on Common Market 2.0, with the Scottish Nationalists being accused (in the second round) of similar strategic voting. This time, reshuffling the tactical abstentions would not be enough to produce a positive majority, and thus we need to assume some tactical opponents as well. ${ }^{1}$ The same short-sighted behaviour has been adopted by supporters of other soft options, and apparently even between no-deal supporters and those in favour of contingent preferential agreements, although, in the latter case, more cooperative behaviours would not have changed their overall negative results. A constitutive element of this lack of cooperation consists in the limited cross-party mutual trust. Table A.1 illuminates this aspect by exploring the distribution of supporters of the different options.

\footnotetext{
${ }^{1}$ Actually, in the first round, all the Scottish Nationalists refrained from voting in favour of both motions.
} 
Table A.1. Cross-party support for the eight plus four motions

\begin{tabular}{|c|c|c|c|c|c|c|c|c|}
\hline & Con & DUP & Green & Ind & Lab & LibDem & $\mathrm{PC}$ & SNP \\
\hline No deal & 157 & 0 & 0 & 0 & 3 & 0 & 0 & 0 \\
\hline Preferential agreement & 126 & 10 & 0 & 0 & 3 & 0 & 0 & 0 \\
\hline Customs union & 34 & 0 & 0 & 2 & 228 & 1 & 0 & 0 \\
\hline EFTA - EEA & 59 & 0 & 0 & 1 & 4 & 0 & 0 & 0 \\
\hline Common market 2.0 & 37 & 0 & 0 & 3 & 144 & 1 & 4 & 0 \\
\hline Labour plan & 1 & 0 & 0 & 2 & 234 & 0 & 0 & 0 \\
\hline Confirmatory referendum & 11 & 0 & 1 & 3 & 206 & 11 & 4 & 32 \\
\hline Revoke art. 50 & 13 & 0 & 1 & 3 & 119 & 10 & 4 & 34 \\
\hline Customs union & 36 & 0 & 0 & 6 & 230 & 1 & 0 & 0 \\
\hline Common market 2.0 & 32 & 0 & 0 & 6 & 185 & 2 & 4 & 32 \\
\hline Confirmatory referendum & 14 & 0 & 1 & 16 & 203 & 11 & 4 & 31 \\
\hline Parliamentary supremacy & 9 & 0 & 1 & 14 & 121 & 10 & 4 & 32 \\
\hline
\end{tabular}




\section{Agreement indices}

To provide greater insight into the cohesion of each parliamentary group, in Table A.2 we report the agreement index for the various parties on each indicative division, together with their overall averages. The index is computed for each group according to the following formula:

$$
\mathrm{AI}=\operatorname{Max}[\mathrm{Y}, \mathrm{N}, \mathrm{A}]-1 / 2[(\mathrm{Y}+\mathrm{N}+\mathrm{A})-\mathrm{Max}[\mathrm{Y}, \mathrm{N}, \mathrm{A}]] /(\mathrm{Y}+\mathrm{N}+\mathrm{A})
$$

Where $\mathrm{Y}$ represents the number of Ayes, $\mathrm{N}$ the number of Noes, and A those who did not participate in the division. The index takes the minimum value of 0 when the MPs evenly split among the three options, and the maximum value of 1 when they vote as a bloc. All other things being equal, it is clearly more likely for larger parties to have lower agreement indices. In fact, apart from the group of independent MPs, the Conservative and the Labour parliamentary parties were, in that order, the least cohesive groups.

Table A.2.Agreement index by party on the indicative and meaningful votes

\begin{tabular}{|c|c|c|c|c|c|c|c|c|}
\hline & Con & DUP & Green & Ind & Lab & LibDem & $\mathrm{PC}$ & SNP \\
\hline No deal & 0.25 & 0.85 & 1.00 & 0.57 & 0.96 & 1.00 & 1.00 & 0.96 \\
\hline Preferential agreement & 0.58 & 1.00 & 1.00 & 0.14 & 0.36 & 0.73 & 1.00 & 1.00 \\
\hline Customs union & 0.46 & 1.00 & 1.00 & 0.36 & 0.29 & 0.73 & 1.00 & 0.96 \\
\hline EFTA - EEA & 0.63 & 1.00 & 1.00 & 0.14 & 0.85 & 0.73 & 1.00 & 1.00 \\
\hline Common market 2.0 & 0.82 & 1.00 & 1.00 & 0.14 & 0.88 & 0.73 & 1.00 & 1.00 \\
\hline Labour plan & 0.73 & 1.00 & 1.00 & 0.14 & 0.20 & 0.86 & 1.00 & 0.96 \\
\hline Confirmatory referendum & 0.71 & 1.00 & 1.00 & 0.14 & 0.72 & 1.00 & 1.00 & 0.87 \\
\hline Revoke art. 50 & 0.10 & 1.00 & 1.00 & 0.57 & 0.94 & 1.00 & 1.00 & 0.91 \\
\hline Customs union & 0.63 & 1.00 & 1.00 & 0.36 & 0.86 & 0.18 & 1.00 & 1.00 \\
\hline Common market 2.0 & 0.60 & 1.00 & 1.00 & 0.14 & 0.60 & 0.18 & 1.00 & 0.87 \\
\hline
\end{tabular}




\begin{tabular}{lcccccccc} 
Confirmatory referendum & 0.70 & 1.00 & 1.00 & 0.14 & 0.75 & 1.00 & 1.00 & 0.83 \\
Parliamentary supremacy & 0.73 & 1.00 & 1.00 & 0.14 & 0.26 & 0.86 & 1.00 & 0.87 \\
& & & & & & & & \\
\hline Average indicative & 0.58 & 0.99 & 1.00 & 0.25 & 0.64 & 0.75 & 1.00 & 0.94 \\
\hline First meaningful vote & 0.43 & 1.00 & 1.00 & 0.36 & 0.97 & 1.00 & 1.00 & 1.00 \\
Second meaningful vote & 0.62 & 1.00 & 1.00 & 0.36 & 0.96 & 1.00 & 1.00 & 1.00 \\
Third meaningful vote & 0.81 & 1.00 & 1.00 & 0.14 & 0.94 & 1.00 & 1.00 & 0.96 \\
& & & & & & & & \\
\hline Average meaningful & 0.62 & 1.00 & 1.00 & 0.29 & 0.96 & 1.00 & 1.00 & 0.99 \\
& & & & & & & & \\
\hline
\end{tabular}

\section{Maps and dimensions}

The aggregating procedure explained in the text is based on discrete ordinal preferences, which are exhibited either by supporting, abstaining or rejecting any motion put to a vote. As such, abstention does not need to be equally 'distant' from ayes and noes, as long as it is perceived as middling between the other two voting options. It could also be perfectly reasonable for a moderate MP to vote against opposite motions, such as triggering a no-deal exit and the revocation of article 50, retaining his/her internal coherence, and yet contributing to produce the typical collective paradox of intransitivity that prevents the success of the preferred moderate options (Riker 1961). The procedure returns a two-dimensional space, in which the location of each MP can now be approximated linearly as Euclidean distances. Most importantly, proximities on both dimensions are even visibly only partially related to party belongings, which makes this space at odd with the tradition and behaviour of MPs in a Westminster's party government (Hix and Noury 2015).

It should be noted that, substantially speaking, a similar interpretation of Brexit related divisions has been provided by some qualitative accounts of the process (Lynch et al. 2019) and, most importantly, adopting entirely different aggregating procedures, e.g. starting from similarity scores between pairs 
of MPs in the perspective of a social network approach. 'The network analysis showed that while there are two distinct (ideology) clusters on both the Brexit and the nonBrexit case, the interconnectivities across these clusters differ significantly. In non-Brexit divisions, it is almost certain that MPs follow the party rhetoric, and defying the party whip is largely negligible. As demonstrated by the network visualisation, most cross-party alliances happen within one cluster only and rarely does it ever cross to the other side. Meanwhile, within-party conflicts are also very minimal. On the other hand, in the Brexit divisions, there was a visible blurring of the party line, and cross-cluster interaction is obvious and apparent. There exists strong repulsion across various node pairs, and while in the non-Brexit case, cross-party alliances only happen within a cluster, it is evident that in the Brexit case, cross-party alliances could happen across two clusters that intuitively have polarised ideological beliefs' (Intal and Yasseri 2019: 27: 27).

If we extend our analyses to the whole set of Brexit related divisions in year 2019 - we counted more than 80 , and the complete list is reported at the end of this appendix - we still need two linear dimensions to represent the behaviour of MPs (see figure A.3). Moreover, we again register an 'anomalous' amount of overlap amongst MPs belonging to opposite parties, though not as large as the one on our subset of fifteen votes. 


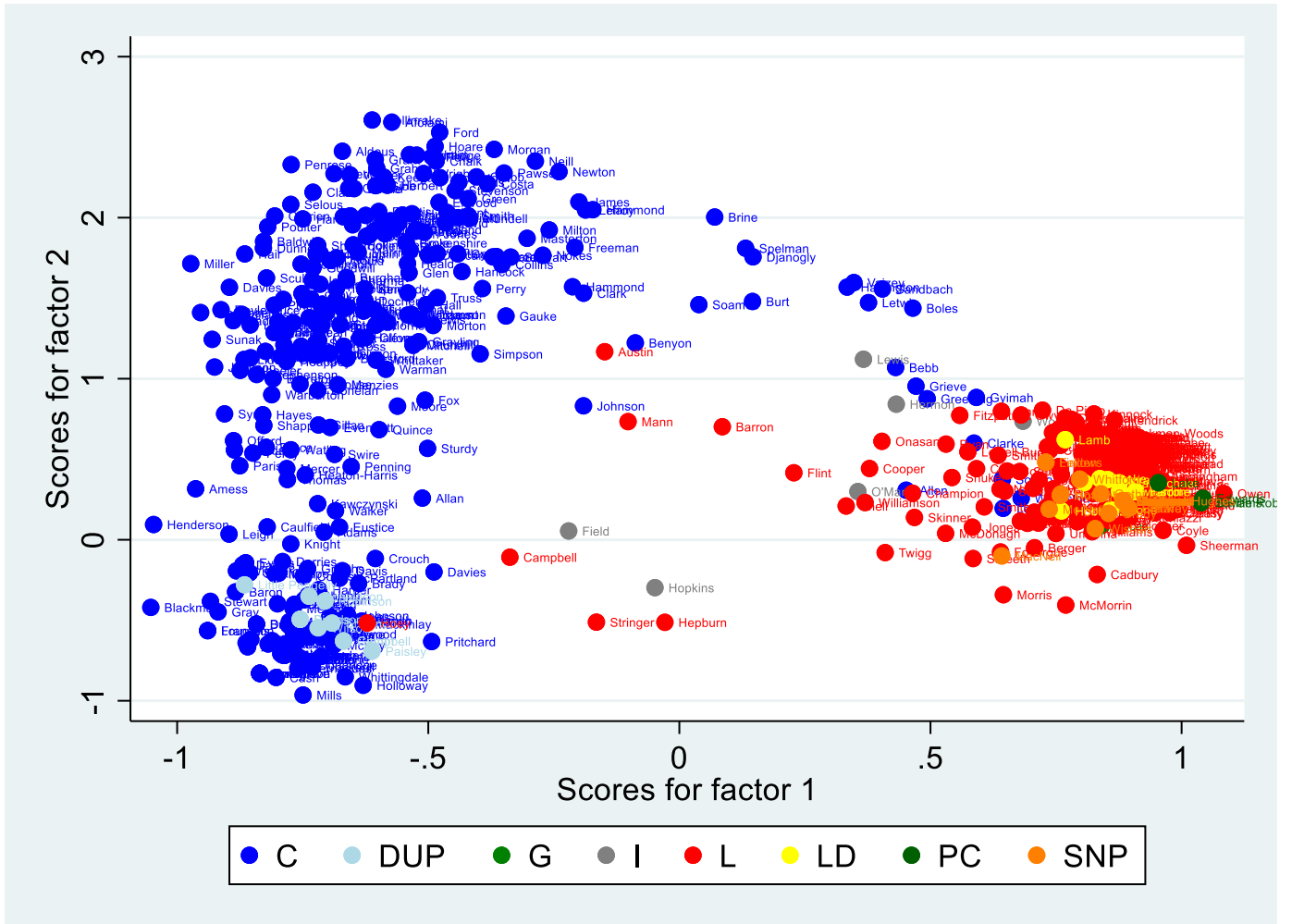

Fig. A.3 The Map of MPs on 84 Brexit-related divisions

However, the latter graph is much more 'clustered' than the one picturing the indicative and meaningful divisions in the article, and lends itself also to an interpretation on the basis of a single curvilinear relationship. In fact, the squared values of the scores of the first dimension explain approximately $18 \%$ of the locations on the second dimension.

Even if the map presented in the article is much more dispersed than the one in figure A.3, one could argue that it also lends to that curvilinear interpretation. In reality, for our fifteen divisions, that approach explains only $0.5 \%$ of the variance on the second dimension, so that the expected curvilinear relationship cannot be easily discerned from the data (see Figure A.4). Moreover, especially considering the wide confidence intervals, the horizontal distances on the first dimension do not differ much from those that would derive following that curvilinear approach. 
However, overcoming that limit, what would be the consequences of that interpretation for what we describe in the rest of the article? Having one single curvilinear political space instead of two orthogonal dimensions certainly affects the (few) associations that we present in the second panel of Figure 2 in the article concerning the relationship between Census data and our second dimension. However, it would probably affect very marginally those concerning the first dimension, since those linear differences would be only spread out more widely following the curvilinear distances. The same could be said for what we found in the last part of the article concerning the issue of responsiveness and compromise, something that we tackle exclusively on the basis of the horizontal dimension and distances.

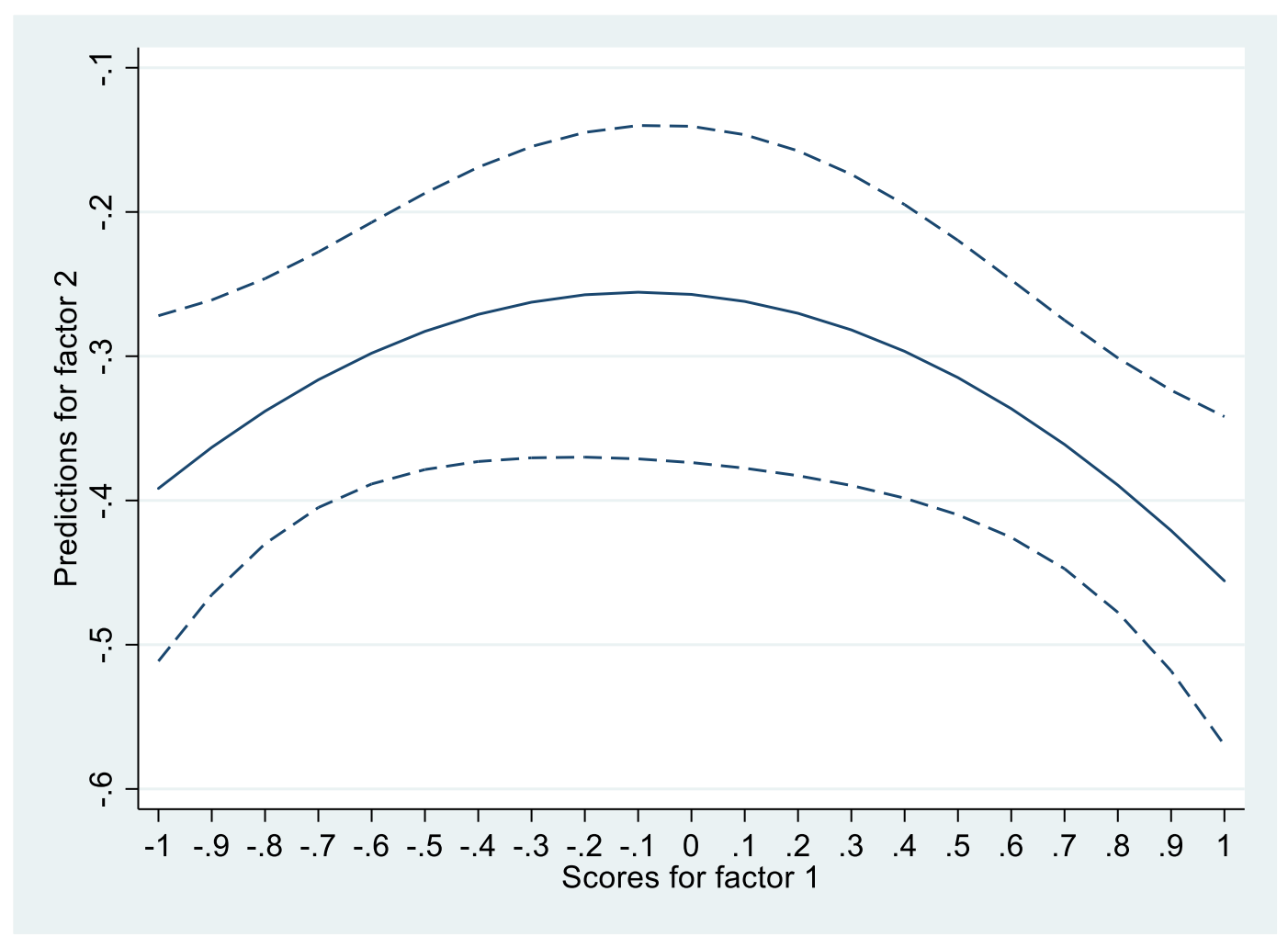

Fig. A.4 A curvilinear interpretation of the map of MPS on the 15 indicative and meaningful votes 
Eventually, combining qualitative reconstructions, the results of other statistical approaches, the plausibility of a curvilinear interpretation and the substantive consequences of the latter approach, we are confident about the plausibility of our two-dimensional interpretation.

Below, we also include a series of maps similar to the one in the article, but this time including the government membership and the names of some relevant MPs, classified according to their UK country of election, and by the number of Ayes in the twelve indicative votes. Clearly, there is no relationship between country and position on the map (figure A.6), whereas the more they are placed on the right-hand side in figure A.7, the more they compromise voting not just for their preferred option.

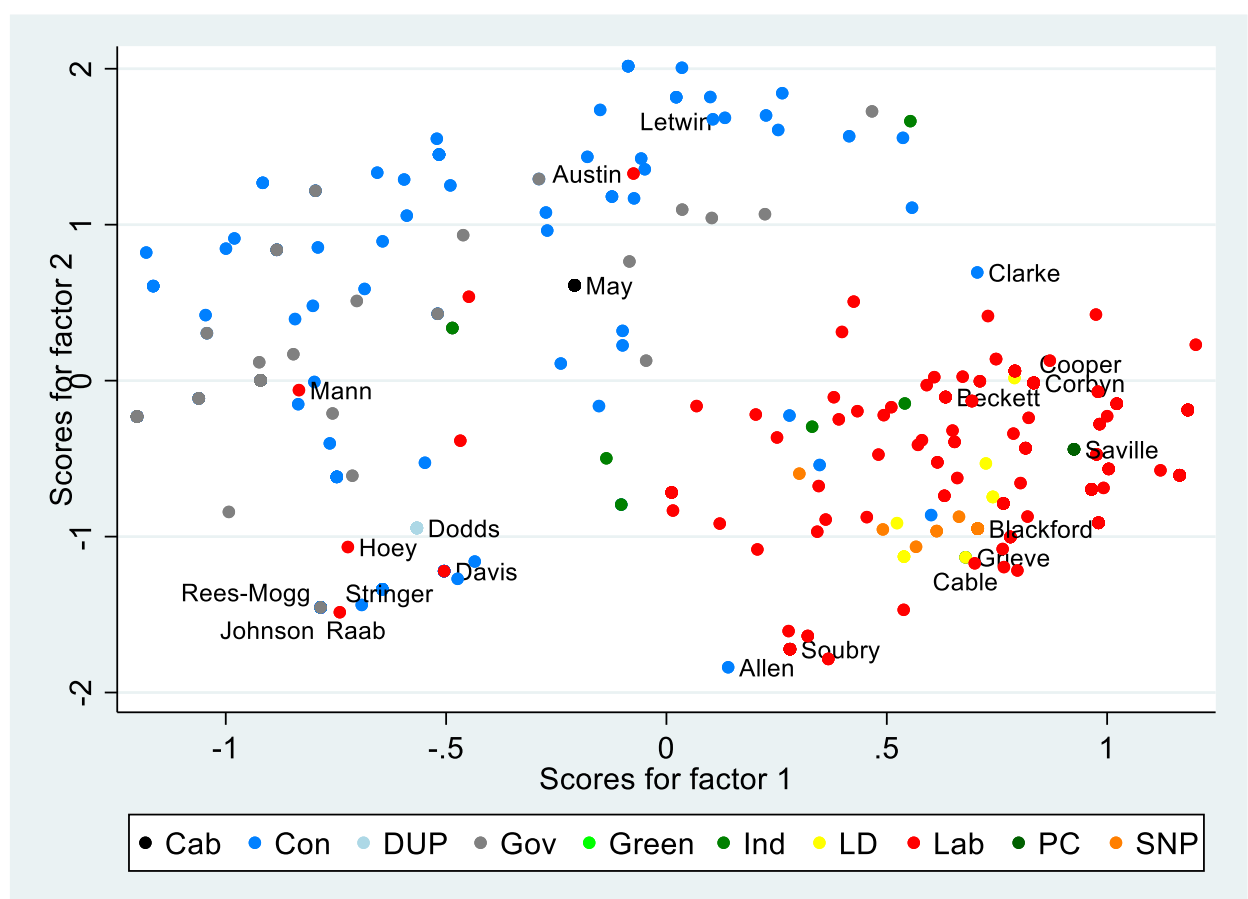

Fig. A.5 The Map of MPs on indicative and meaningful votes with cabinet/government belongings and position of some prominent MPs 


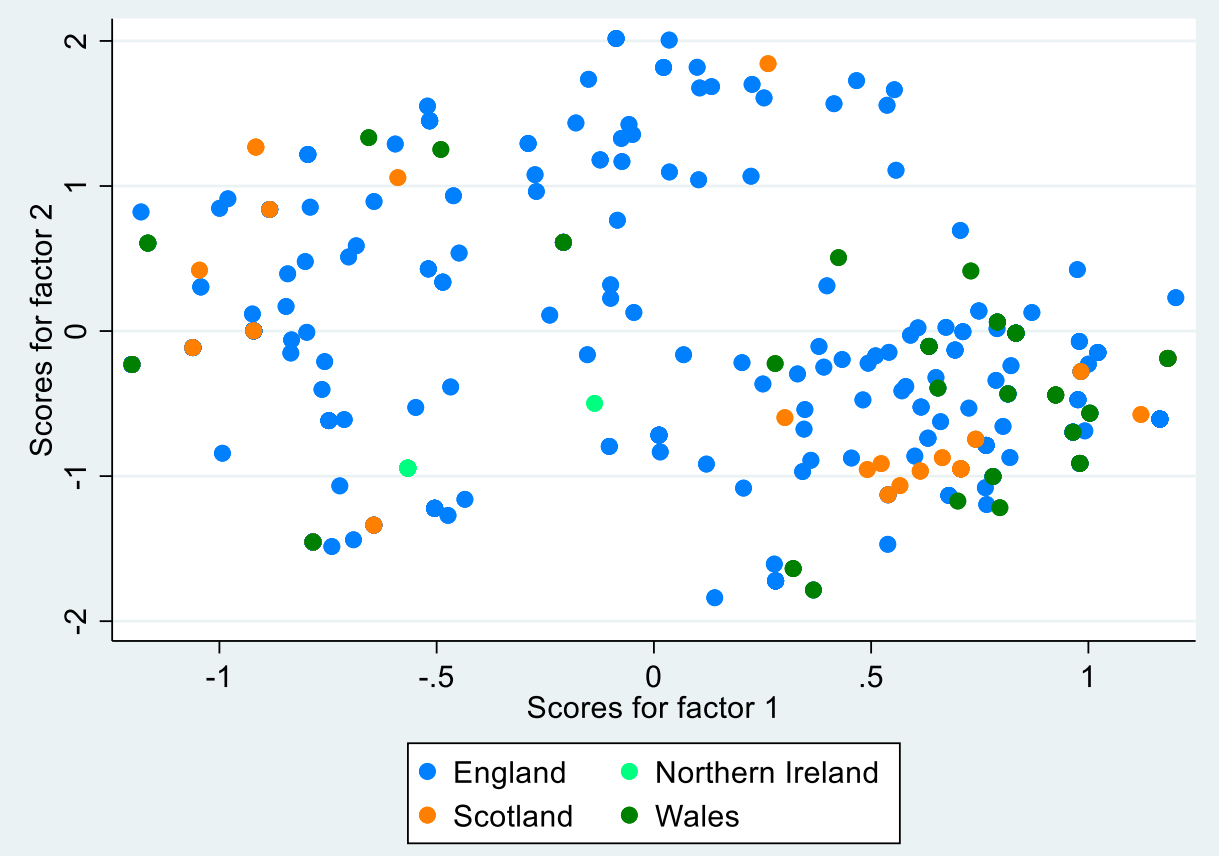

Fig. A.6 The Map of MPs on indicative and meaningful votes classified by country of election

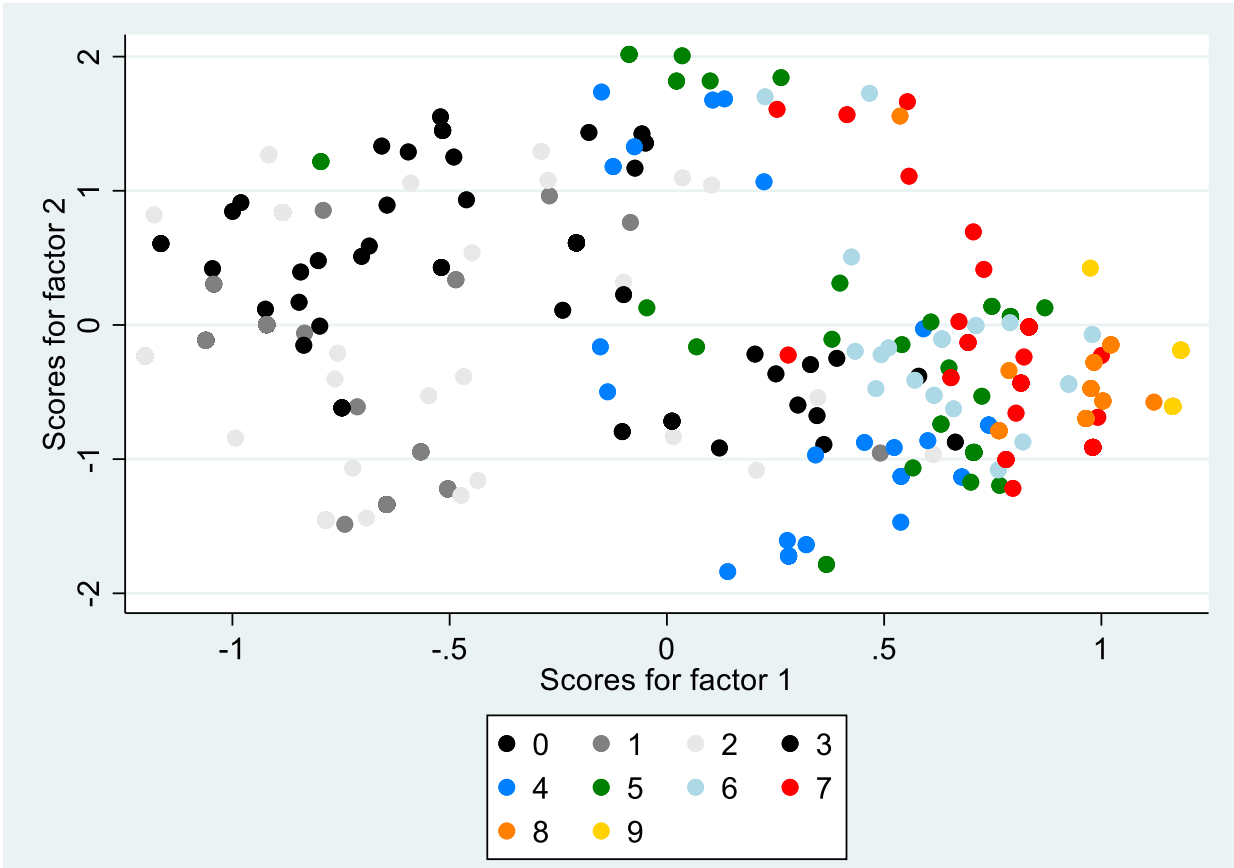

Fig. A.7 The Map of MPs classified for number of ayes in the twelve indicative votes 



\section{Background models}

For a better clarity, figure 2 in the article compares standardized coefficients of the described bivariate models. For completeness, we report below also the representation of the original coefficients together with the tables producing them.

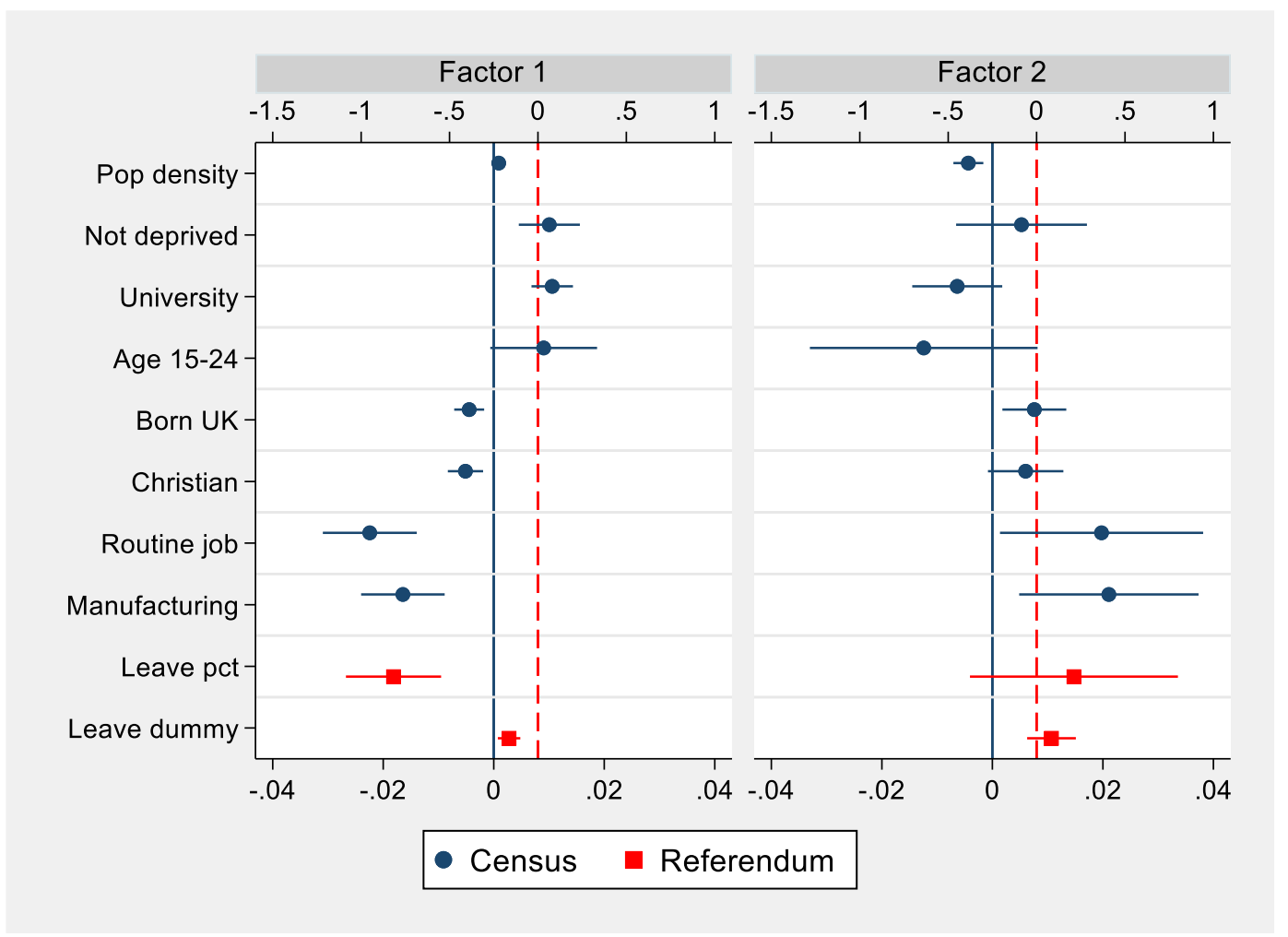

Fig. A.8 Raw coefficients of the bivariate models presented in Figure 2

On the left-hand side, we evaluate the determinants of the scores on the first dimension of the map, while on the right-hand side, we compare the corresponding values for the second dimension. The scale for the coefficients of the census covariates is located at the bottom of the graph, and the corresponding zero line is solid; the scale corresponding to the coefficients for the referendum results is at the top, and the null value is reported with a dashed vertical line. 
In Tables A.3 and A.4 we report the coefficients of the regressions that produced figure 2 in the article. They are all OLS regression with party fixed effect and robust standard errors. The varying number of cases should be attributed to the fact that census data are not homogeneous across all countries of the United Kingdom 
Tab. A.3 Original regressions for left panel of Figure 2 in the article (raw coefficients were then standardized according to (Gelman 2008))

\begin{tabular}{|c|c|c|c|c|c|}
\hline & $(1)$ & $(2)$ & (3) & $(4)$ & $(5)$ \\
\hline Pop density & $\begin{array}{c}0.001 \\
(0.001)\end{array}$ & & & & \\
\hline Not deprived & & $\begin{array}{c}0.010 * * * \\
(0.003)\end{array}$ & & & \\
\hline University & & & $\begin{array}{c}0.011 * * * \\
(0.002)\end{array}$ & & \\
\hline Age $15-24$ & & & & $\begin{array}{c}0.009 * * \\
(0.004)\end{array}$ & \\
\hline Born UK & & & & & $\begin{array}{c}-0.004 * * * \\
(0.001)\end{array}$ \\
\hline Constant & $\begin{array}{c}-0.664 * * * \\
(0.024)\end{array}$ & $\begin{array}{c}-1.114 * * * \\
(0.123)\end{array}$ & $\begin{array}{c}-0.823 * * * \\
(0.039)\end{array}$ & $\begin{array}{c}-0.759 * * * \\
(0.051)\end{array}$ & $\begin{array}{l}-0.250^{*} \\
(0.133)\end{array}$ \\
\hline Party fixed effects & $\checkmark$ & $\checkmark$ & $\checkmark$ & $\checkmark$ & $\checkmark$ \\
\hline \multirow[t]{2}{*}{ Observations } & 638 & 568 & 568 & 627 & 638 \\
\hline & (6) & (7) & $(8)$ & (9) & $(10)$ \\
\hline Christian & $\begin{array}{c}-0.005^{* * * *} \\
(0.002)\end{array}$ & & & & \\
\hline Routine job & & $\begin{array}{c}-0.022 * * * \\
(0.004)\end{array}$ & & & \\
\hline Manufacturing & & & $\begin{array}{c}-0.016 * * * \\
(0.004)\end{array}$ & & \\
\hline Leave pct & & & & $\begin{array}{c}-0.817 * * * \\
(0.161)\end{array}$ & \\
\hline Leave dummy & & & & & $\begin{array}{c}-0.163 * * * \\
(0.034)\end{array}$ \\
\hline Constant & $\begin{array}{c}-0.335^{* * * *} \\
(0.099)\end{array}$ & $\begin{array}{c}-0.422 * * * \\
(0.053)\end{array}$ & $\begin{array}{c}-0.502 * * * \\
(0.044)\end{array}$ & $\begin{array}{c}-0.206 * * \\
(0.095)\end{array}$ & $\begin{array}{c}-0.533 * * * \\
(0.037)\end{array}$ \\
\hline Party fixed effects & $\checkmark$ & $\checkmark$ & $\checkmark$ & $\checkmark$ & $\checkmark$ \\
\hline Observations & 638 & 638 & 627 & 638 & 638 \\
\hline
\end{tabular}

Robust standard errors in parentheses; $* * * \mathrm{p}<0.01, * * \mathrm{p}<0.05, * \mathrm{p}<0.1$ 
Tab. A.4 Original regressions for right panel of Figure 2 in the article (raw coefficients were then standardized according to (Gelman 2008))

\begin{tabular}{|c|c|c|c|c|c|}
\hline & $(1)$ & (2) & (3) & (4) & $(5)$ \\
\hline Pop density & $\begin{array}{c}-0.004 * * * \\
(0.001)\end{array}$ & & & & \\
\hline Not deprived & & $\begin{array}{c}0.005 \\
(0.006)\end{array}$ & & & \\
\hline University & & & $\begin{array}{c}-0.006^{*} \\
(0.004)\end{array}$ & & \\
\hline Age $15-24$ & & & & $\begin{array}{l}-0.012 \\
(0.009)\end{array}$ & \\
\hline Born UK & & & & & $\begin{array}{c}0.008 * * * \\
(0.002)\end{array}$ \\
\hline Constant & $\begin{array}{c}-0.148 * * \\
(0.059)\end{array}$ & $\begin{array}{l}-0.451 \\
(0.277)\end{array}$ & $\begin{array}{l}-0.106 \\
(0.081)\end{array}$ & $\begin{array}{l}-0.047 \\
(0.111)\end{array}$ & $\begin{array}{c}-0.883 * * * * \\
(0.215)\end{array}$ \\
\hline Party fixed effects & $\checkmark$ & $\checkmark$ & $\checkmark$ & $\checkmark$ & $\checkmark$ \\
\hline \multirow[t]{2}{*}{ Observations } & 638 & 568 & 568 & 627 & 638 \\
\hline & (6) & $(7)$ & $(8)$ & $(9)$ & $(10)$ \\
\hline Christian & $\begin{array}{c}0.006 * * \\
(0.003)\end{array}$ & & & & \\
\hline Routine job & & $\begin{array}{c}0.020 * * \\
(0.009)\end{array}$ & & & \\
\hline Manufacturing & & & $\begin{array}{c}0.021 * * * \\
(0.008)\end{array}$ & & \\
\hline Leave pct & & & & $\begin{array}{c}0.211 \\
(0.287)\end{array}$ & \\
\hline Leave dummy & & & & & $\begin{array}{c}0.084 \\
(0.071)\end{array}$ \\
\hline Constant & $\begin{array}{c}-0.567 * * * \\
(0.173)\end{array}$ & $\begin{array}{c}-0.396 * * * \\
(0.110)\end{array}$ & $\begin{array}{c}-0.386 * * * \\
(0.092)\end{array}$ & $\begin{array}{c}-0.307 * \\
(0.173)\end{array}$ & $\begin{array}{c}-0.254 * * * \\
(0.080)\end{array}$ \\
\hline Party fixed effects & $\checkmark$ & $\checkmark$ & $\checkmark$ & $\checkmark$ & $\checkmark$ \\
\hline Observations & 638 & 638 & 627 & 638 & 638 \\
\hline
\end{tabular}

Robust standard errors in parentheses; *** $\mathrm{p}<0.01, * * \mathrm{p}<0.05, * \mathrm{p}<0.1$ 
Running a Breusch-Pagan/Cook-Weisberg test and a White's test, we realized that regressing the scores on the first dimension on the percentage of Leave votes interacted with the electoral margin in the 2017 election posed a problem of heteroskedasticity. This time, instead of simply modifying the standard errors for more robust evidence, we modelled the errors according to our theoretical expectations. We thus ran a heteroskedastic regression in which the variance around our estimate depended on the date of first election, with senior MPs (i.e. smaller year) expected to have larger freedom margins and thus greater variance. This is the first model below, which produced the marginal effect for the interaction plotted in figure 3 in the article. The likelihood-ratio test at the bottom of the table confirms that our model of the variance fits the data better than a usual OLS with constant variance.

We also inverted the variables, as in model (2), interacting the year of election and modelling the variance though the electoral margin. However, the coefficients, the likelihood-ratio test, and the marginal effects (plotted below in figure A.9) are not as interesting.

Tab. A.5 Heteroskedastic regressions. Model (1) for figure 3 in the article, and model (2) reversing the interaction and variance modelling (s.e. in parentheses)

(1)

(2)

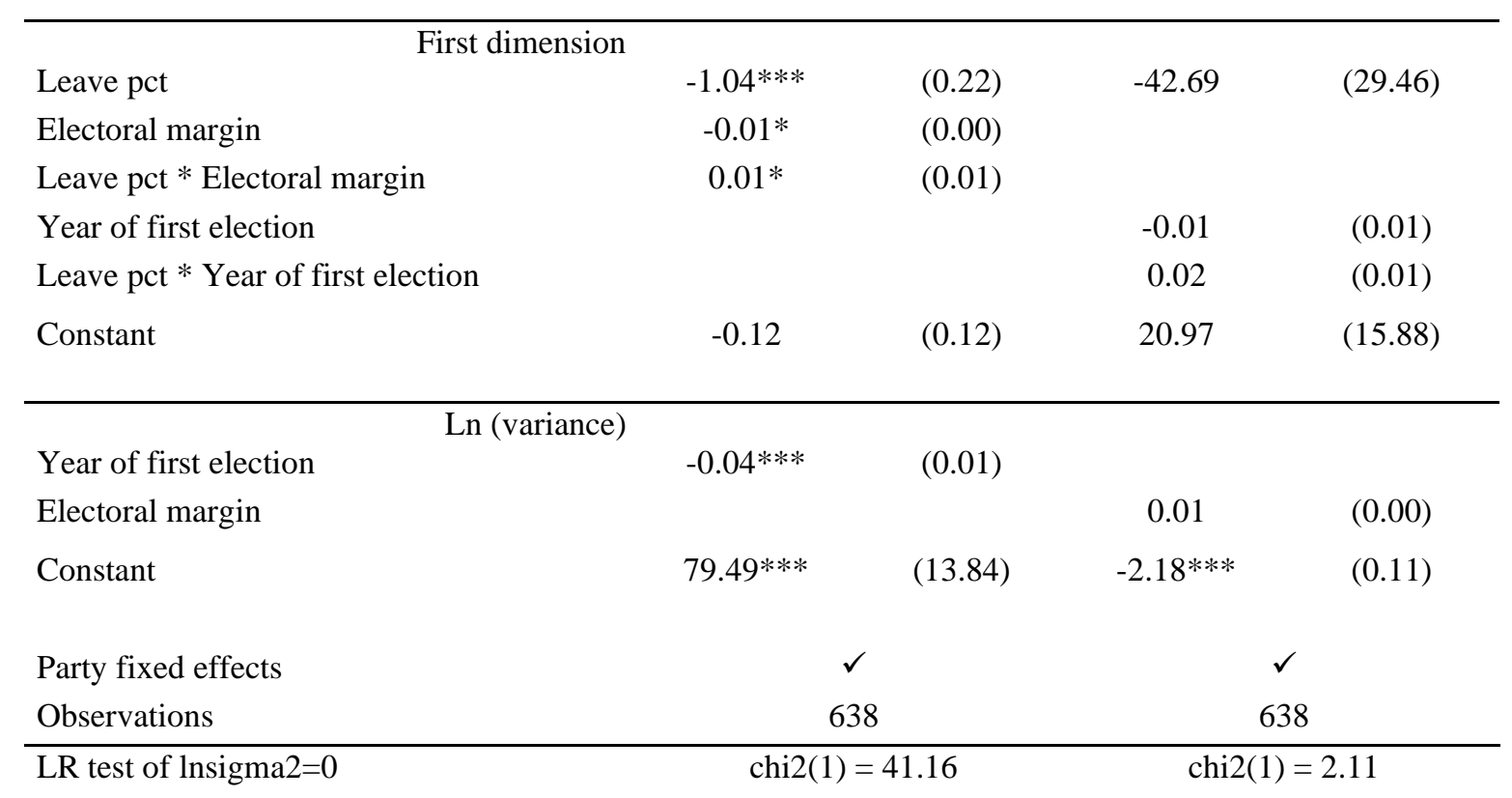




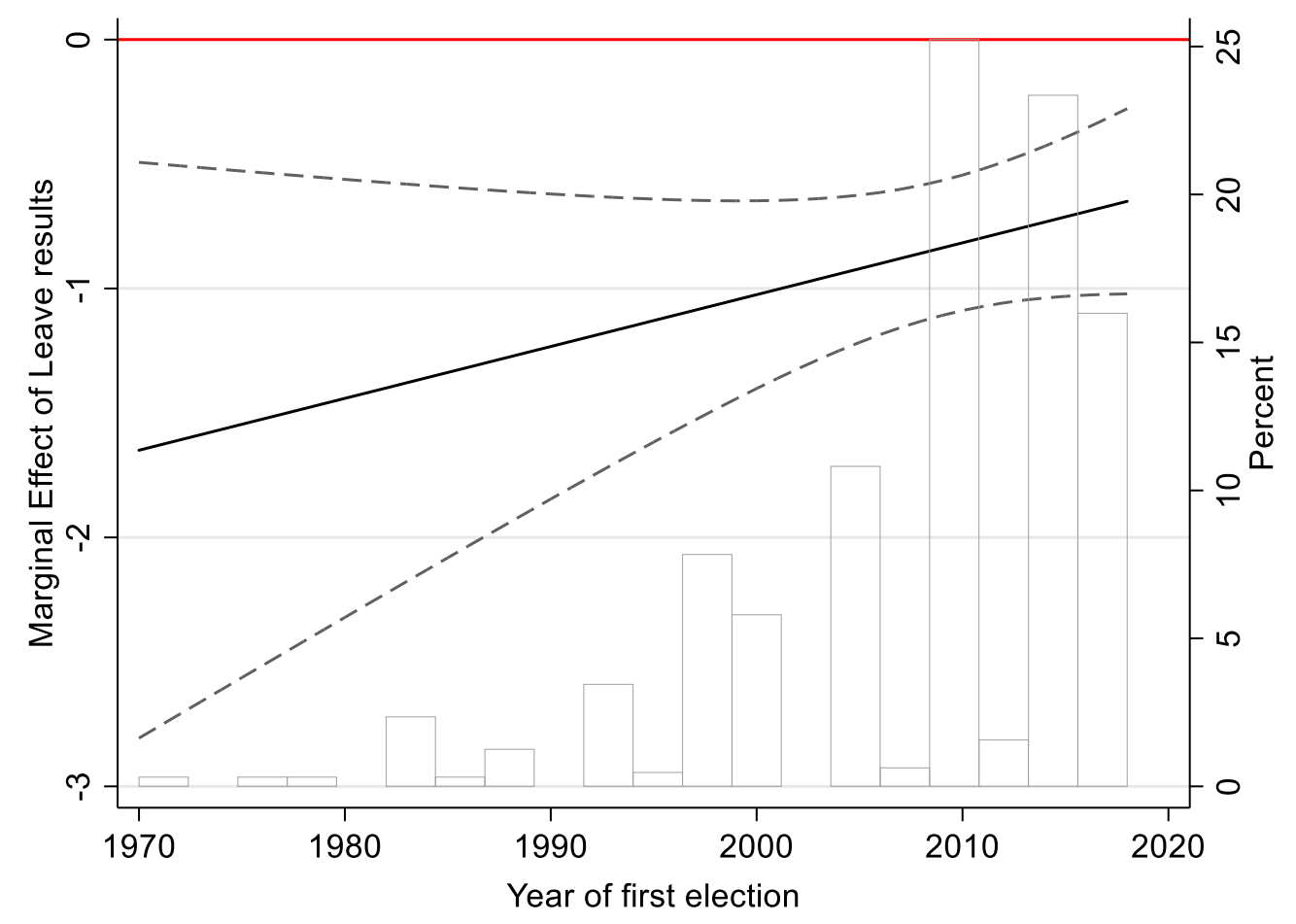

Fig. A.9 Marginal effect of Leave pct at different years of election (model (2) reported and described above) 


\section{Responsiveness and compromise}

The following tables report some regression models complementing the analysis of the electoral costs of non-responsiveness and of compromise reported in the article.

In Table A.6 we highlight that, all other things being equal, Conservative MPs who 'betrayed' the preferences of their constituencies were sanctioned more than their Labour colleagues on both sides of the Brexit divide. The combination with Tory incumbents in Leave districts (model 1) is the one producing the higher magnitude and significance for the relevant coefficient, while the opposite type of betrayal, with Labour incumbents in Remain districts (model 4), is the one who is farther away from offering any systematic effect.

Table A.6 Non-responsiveness and electoral consequences

\begin{tabular}{|c|c|c|c|c|}
\hline & $\begin{array}{c}\text { (1) } \\
\text { Delta votes } \\
\text { Leave Con districts }\end{array}$ & $\begin{array}{c}(2) \\
\text { Delta votes } \\
\text { Leave Lab districts }\end{array}$ & $\begin{array}{c}(3) \\
\text { Delta votes } \\
\text { Remain Con } \\
\text { districts } \\
\end{array}$ & $\begin{array}{c}\text { (4) } \\
\text { Delta votes } \\
\text { Remain Lab districts }\end{array}$ \\
\hline Non-responsiveness & $\begin{array}{c}-3.08 * * * \\
(0.78)\end{array}$ & $\begin{array}{l}-2.95 \\
(1.83)\end{array}$ & $\begin{array}{c}-2.37 * * \\
(1.09)\end{array}$ & $\begin{array}{l}-0.22 \\
(2.27)\end{array}$ \\
\hline Margin 2017 & $\begin{array}{c}-0.11 * * * \\
(0.02)\end{array}$ & $\begin{array}{c}0.01 \\
(0.02)\end{array}$ & $\begin{array}{c}-0.13 * * * \\
(0.02)\end{array}$ & $\begin{array}{l}-0.02 \\
(0.02)\end{array}$ \\
\hline Change turnout & $\begin{array}{c}-0.79 * * * \\
(0.16)\end{array}$ & $\begin{array}{c}0.16 \\
(0.21)\end{array}$ & $\begin{array}{c}-0.74 * * * \\
(0.14)\end{array}$ & $\begin{array}{c}0.37 * * * \\
(0.06)\end{array}$ \\
\hline Constant & $\begin{array}{c}6.31 * * * \\
(0.56)\end{array}$ & $\begin{array}{c}-10.36^{* * * *} \\
(0.86)\end{array}$ & $\begin{array}{c}0.63 \\
(0.78)\end{array}$ & $\begin{array}{c}-4.24 * * * \\
(0.88)\end{array}$ \\
\hline Observations & 236 & 151 & 80 & 103 \\
\hline
\end{tabular}


In Table A.7 (model 1 and 2) we note that when Conservative MPs decided to step down and not compete in the 2019 election - something that happened mostly due to the divergences between the new prime minister and those Tories wanting to avoid a hard exit at all costs - the party suffered a larger electoral retreat due to the compromising attitude of its representatives compared to districts in which the incumbent Tory MP was confirmed as candidate. This result is even stronger if we added the share of leave votes in the 2016 referendum as control variable. However, our analysis cannot confirm that this happened because the electorate did not support the new candidates, or because it sanctioned the behaviour of their previous representatives by changing their vote.

Table A.7 Compromise and electoral consequences

\begin{tabular}{|c|c|c|c|c|}
\hline & $\begin{array}{c}(1) \\
\begin{array}{c}\text { Delta Con votes Not } \\
\text { substituted }\end{array} \\
\end{array}$ & $\begin{array}{c}(2) \\
\text { Delta Con votes } \\
\text { Substituted } \\
\end{array}$ & $\begin{array}{c}(3) \\
\text { Delta Lab votes } \\
\text { Con districts } \\
\end{array}$ & $\begin{array}{c}\text { (4) } \\
\text { Delta Con votes } \\
\text { Lab districts } \\
\end{array}$ \\
\hline First dimension & $\begin{array}{l}-1.52^{*} \\
(0.78)\end{array}$ & $\begin{array}{c}-3.13 * * * \\
(0.91)\end{array}$ & $\begin{array}{l}-0.12 \\
(0.49)\end{array}$ & $\begin{array}{c}-1.93 * * * \\
(0.74)\end{array}$ \\
\hline Margin 2017 & $\begin{array}{c}-0.10 * * * \\
(0.02)\end{array}$ & $\begin{array}{c}-0.13 * * * \\
(0.04)\end{array}$ & $\begin{array}{l}-0.02 \\
(0.01)\end{array}$ & $\begin{array}{c}-0.45 * * * \\
(0.01)\end{array}$ \\
\hline Change turnout & $\begin{array}{c}-1.39 * * * \\
(0.16)\end{array}$ & $\begin{array}{c}-0.87 * * * \\
(0.27)\end{array}$ & $\begin{array}{c}0.14 \\
(0.14)\end{array}$ & $\begin{array}{l}-0.09 \\
(0.15)\end{array}$ \\
\hline Constant & $\begin{array}{c}2.21 \\
(0.79)\end{array}$ & $\begin{array}{c}2.21 * * \\
(0.98)\end{array}$ & $\begin{array}{c}-6.63 * * * \\
(0.64)\end{array}$ & $\begin{array}{c}4.11 * * * \\
(0.80)\end{array}$ \\
\hline Observations & 267 & 49 & 316 & 254 \\
\hline
\end{tabular}

In models 3 and 4, we check the consequences for the Labour party in districts with a Tory MP ready to compromise, and those for the Conservative party in similarly led Labour districts. While the losses in Conservative districts that we reported in the article are not complemented with comparable gains for the main opposition party, the wins in Labour districts were actually matched by systematic losses for the Conservative candidates. 


\section{Extended list of EU divisions}

Division Date

$291 \quad 09 / 01 / 2019$

$15 / 01 / 2019$

$15 / 01 / 2019$

$16 / 01 / 2019$

$29 / 01 / 2019$

$29 / 01 / 2019$

$29 / 01 / 2019$

$29 / 01 / 2019$

$29 / 01 / 2019$

$29 / 01 / 2019$

29/01/2019

UK Withdraw

$14 / 02 / 2019$

$14 / 02 / 2019$

$27 / 02 / 2019$

$27 / 02 / 2019$

$27 / 02 / 2019$

$12 / 03 / 2019$

$13 / 03 / 2019$

$13 / 03 / 2019$

$13 / 03 / 2019$

$14 / 03 / 2019$

$14 / 03 / 2019$

$14 / 03 / 2019$

$14 / 03 / 2019$

$14 / 03 / 2019$

$25 / 03 / 2019$

$25 / 03 / 2019$

$25 / 03 / 2019$

$27 / 03 / 2019$

$27 / 03 / 2019$

$27 / 03 / 2019$

$27 / 03 / 2019$

$27 / 03 / 2019$
Title

Timescale for Setting Out Plan for Negotiations if Proposed Agreement for the UK Withdrawal from the EU is Rejected by MPs - 9 Jan 2019 at 13:57 European Union (Withdrawal) Act - Withdrawal Agreement - Right for the UK to Unilaterally Terminate the Protocol on Ireland / Northern Ireland European Union Withdrawal Agreement - 15 Jan 2019 at 19:00

Motion of No Confidence in Her Majesty's Government - 16 Jan 2019 at 19:00

European Union (Withdrawal) Act 2018 - Consideration of Government Plans - Options to Prevent Withdrawal Without Agreement - Referendum European Union (Withdrawal) Act 2018 - Delay Withdrawal — Rule-Out No-Deal

European Union (Withdrawal) Act 2018 - Prioritising Debate on Withdrawal in the House of Commons - Enabling MPs to Amend Motions -

European Union (Withdrawal) Act 2018 - Seek to Delay Withdrawal Until 31 December 2019 if no Withdrawal Agreement by 26 February 2019

European Union (Withdrawal) Act 2018 - Seek to Delay Withdrawal if no Withdrawal Agreement by 26 February 2019 - 29 Jan 2019 at 19:00

European Union (Withdrawal) Act 2018 - Reject Leaving the European Union Without a Withdrawal Agreement - 29 Jan 2019 at 19:00

European Union (Withdrawal) Act 2018 - Avoid Hard Border on the Island of Ireland Without the UK Remaining Aligned to the EU Customs Union 331 the EU - Withdrawal Agreement - Ireland - 14 Feb 2019 at 17:00

UK Withdrawal from the EU - Delay of up-to Three Months - Ireland - 14 Feb 2019 at 17:00

UK Withdrawal from the EU - Withdrawal Agreement - Ireland - 14 Feb 2019 at 17:00

UK Withdrawal from the EU - Negotiation Aims - 27 Feb 2019 at 18:48

UK Withdrawal from the EU - Leaving Without a Withdrawal Agreement - 27 Feb 2019 at 18:48

UK Withdrawal from the EU - Consideration of a Short Delay if Withdrawal Agreement and Leaving Without an Agreement Rejected -

European Union Withdrawal Agreement - 12 Mar 2019 at 19:00

UK Withdrawal from the European Union - Leaving Without an Agreement - 13 Mar 2019 at 19:00

UK Withdrawal from the European Union - 13 Mar 2019 at 19:00

UK Withdrawal from the European Union - Leaving Without a Withdrawal Agreement - 13 Mar 2019 at 19:00

UK Withdrawal from the EU - Delay Withdrawal to Enable a Further Referendum on Withdrawal to be Held - 14 Mar 2019 at 17:00

UK Withdrawal from the EU - Preventing Delay Withdrawing Continuing Beyond 30 June 2019 - 14 Mar 2019 at 17:00

UK Withdrawal from the EU - Consider Cross Party Proposal To Seek Majority Support in the House of Commons - 14 Mar 2019 at 17:00

UK Withdrawal from the EU - Delay to Avoid Leaving Without a Withdrawal Agreement - 14 Mar 2019 at 17:00

UK Withdrawal from the European Union - Delay Withdrawal if MPs Agree Withdrawal Agreement - 14 Mar 2019 at 17:00

Business of the House - Precedence for Government Business - 25 Mar 2019 at 21:47

Business of the House - Enable MPs to Decide Between Leaving the European Union Without a Withdrawal Agreement and Delaying Withdrawal -

Business of the House - Precedence for Government Business - 25 Mar 2019 at 22:14

Business of the House - Proceedure for Consideration of the UK's Withdrawal From the EU - 27 Mar 2019 at 15:00

EU Withdrawal and Future Relationship - Motion (B) - Leave Without a Deal on 12 April 2019 - 27 Mar 2019 at 22:56

EU Withdrawal and Future Relationship - Motion (D) - Retain Freedom of Movement of People and Goods via EFTA Membership -

EU Withdrawal and Future Relationship - Motion (H) - Retain Relatively Free Movement of People and Goods via EFTA - No Customs Union with EU

EU Withdrawal and Future Relationship - Motion (J) - Customs Union - 27 Mar 2019 at 22:56 
EU Withdrawal and Future Relationship - Motion (K) - Labourâ€ ${ }^{\mathrm{TM}_{S}}$ Alternative Plan - 27 Mar 2019 at 22:56

EU Withdrawal and Future Relationship - Motion (L) - Opportunity to Decide Between Remaining In the EU and Leaving Without a Withdrawal agree EU Withdrawal and Future Relationship Votes - (M) - Public Vote on Withdrawal Agreement and Framework for Future Relationship with the EU EU Withdrawal and Future Relationship - Motion (O) - Seeking Preferential Trade Arrangements To Apply In Absense of Withdrawal Agreement Draft European Union (Withdrawal) Act 2018 (Exit Day) (Amendment) Regulations 2019- Delay Withdrawal from 29 March to 12 April or 22 May UK Withdrawal from the European Union - Withdrawal - Withdrawal Agreement - 29 Mar 2019 at 14:11

Business of the House - Proceedure for Consideration of the UK's Withdrawal From the EU - 1 Apr 2019 at 16:35

EU Withdrawal and Future Relationship - Motion (C) Customs Union - 1 Apr 2019 at 22:53

Motion (D) Common Market 2.0 - Retain Relatively Free Movement of People and Goods via EFTA Membership - External Tariff Alignment with EU

EU Withdrawal and Future Relationship - Motion (E) Confirmatory Public Vote on Withdrawal Agreement and Framework for Future Relationship

Motion (G) Parliamentary Supremacy - MPs to Decide Between Remaining in the EU and Leaving Without a Withdrawal Agreement

Business of the House - Consideration of Motions on EU Withdrawal on 8 April 2019 - 3 Apr 2019 at 17:00

Business of the House - European Union (Withdrawal) (No. 5) Bill - MPs to Decide if to Delay UK Withdrawal from EU - 3 Apr 2019 at 17:00

European Union (Withdrawal) (No. 5) Bill - Second Reading - 3 Apr 2019 at 19:00

European Union (Withdrawal) (No. 5) Bill - Clause 1 - Consideration by MPs of Any Withdrawal Delay Proposed by the European Council -

European Union (Withdrawal) (No. 5) Bill - Clause 1 - Directions for the Prime Minister - 3 Apr 2019 at 22:11

European Union (Withdrawal) (No. 5) Bill - Clause 1 - No Delay to Withdrawal Beyond 22 May 2019 - 3 Apr 2019 at 22:11

European Union (Withdrawal) (No. 5) Bill - New Clause 4 - Amendability of Motions - 3 Apr 2019 at 22:11

European Union (Withdrawal) (No. 5) Bill - Third Reading - 3 Apr 2019 at 22:11

European Union (Withdrawal) (No. 5) Bill - Clause 1 - Arrangements for Moving a Motion on Seeking to Delay the UK Leaving the EU

European Union (Withdrawal) (No. 5) Bill - Clause 1 - Length of Delay to the UK Leaving the EU - 8 Apr 2019 at 22:00

European Union (Withdrawal) (No. 5) Bill - Clause 1 - Alternative Date for the UK Leaving the EU - 8 Apr 2019 at 22:00

Exiting the European Union - Delay Until 30 June 2019 - 9 Apr 2019 at 17:12

Business of the House - Consideration of Motions on EU Withdrawal on 25 June 2019 - 12 Jun 2019 at 16:25

Northern Ireland (Executive Formation) Bill — Progress report

Northern Ireland (Executive Formation) Bill — Progress report

Northern Ireland (Executive Formation) Bill — Progress report

Northern Ireland (Executive Formation) Bill — Progress reports

Northern Ireland (Executive Formation) Bill — Progress reports

Consideration of the European Union (Withdrawal) (No. 6) Bill - Requiring Prime Minister to Seek Delay To Withdrawal

European Union (Withdrawal) (No. 6) Bill — Second Reading — Requiring Prime Minister to Seek Delay to Withdrawal

European Union (Withdrawal) (No. 6) Bill - Clause 1 - Purpose of Delaying Withdrawal — Content of Bill to Implement Withdrawl Agreement

European Union (Withdrawal) (No. 6) Bill — Third Reading — Requiring Prime Minister to Seek Delay to Withdrawal

Early Parliamentary General Election

Provision of Information on Both the Suspension of Parliament and Planning for Leaving the EU Without a Withdrawal Agreement

Early Parliamentary General Election

Draft Environment (Legislative Functions from Directives) (EU Exit) Regulations 2019

Business of the House (Saturday 19 October) - Amendments and Votes

European Union Withdrawal - Withhold Approval of Withdrawal Agreement Unless and Until it is Implemented in UK Law

European Union (Withdrawal Agreement) Bill — Second Reading

European Union (Withdrawal Agreement) Bill (Programme) — Completion of Consideration Within Three Sitting Days 
$23 / 10 / 2019$

$23 / 10 / 2019$

$23 / 10 / 2019$

$24 / 10 / 2019$

$24 / 10 / 2019$

$28 / 10 / 2019$

$29 / 10 / 2019$

$29 / 10 / 2019$

$29 / 10 / 2019$
Draft Freedom of Establishment and Free Movement of Services (EU Exit) Regulations 2019

Draft Statutory Auditors, Third Country Auditors and International Accounting Standards (Amendment) (EU Exit) Regulations 2019

Draft Financial Services (Miscellaneous) (Amendment) (EU Exit) (No. 3) Regulations 2019

Queen's Speech — Programme for Government — Leaving the European Union

Queen's Speech — Programme for Government

Early Parliamentary General Election

Business of the House - Arrangements for Consideration of the Early Parliamentary General Election Bill — Enable Opposition

Early Parliamentary General Election Bill — Clause 1 - Election Date - 9 vs 12 December

Early Parliamentary General Election Bill — Third Reading 


\section{References}

Aidt T et al. (2021) The Meaningful Votes: Voting on Brexit in the British House of Commons. Public Choice 186(3-4), 587-617.

Alexandre-Collier A (2020) From Rebellion to Extinction: Where have all the Tory Remainer MPs Gone? The Political Quarterly 91(1), 24-30.

Auel K and Umit R (2020) Who's the Boss? An analysis of the vote on the 'European Union (Notice of Withdrawal) Bill' in the House of Commons. Journal of Contemporary European Studies doi: 10.1080/14782804.2020.1815679.

Axe-Browne A and Hansen ME (2021) Still dividing the electorate? Brexit and voter evaluation of candidates. Journal of Elections, Public Opinion and Parties 31(2), 220-242.

Baldini G et al. (2021) Back to the Westminster model? The Brexit process and the UK political system. International Political Science Review doi: $10.1177 / 0192512120967375$.

Benedetto G and Hix S (2007) The Rejected, the Ejected, and the Dejected: Explaining Government Rebels in the 2001-2005 British House of Commons. Comparative Political Studies 40(7), 755-781.

Blomgren M and Rozenberg $\mathbf{O}$ (eds.) (2012) Parliamentary Roles in Modern Legislatures. London: Routledge.

Boyle M et al. (2018) Introducing 'Brexit Geographies': five provocations. Space and Polity 22(2), 97-110.

Brusenbauch Meislova M (2019) Brexit Means Brexit—or Does It? The Legacy of Theresa May's Discursive Treatment of Brexit. The Political Quarterly 90, 681689.

Burke E (1999) Select Works of Edmund Burke, vol. 4 [1774]. Indianapolis: Liberty Fund.

Carey JM (2007) Competing Principals, Political Institutions, and Party Unity in Legislative Voting. American Journal of Political Science 51(1), 92-107.

Carreras M et al. (2019) Long-Term Economic Distress, Cultural Backlash, and Support for Brexit. Comparative Political Studies 52(9), 1396-1424.

Colantone I and Stanig P (2018) Global Competition and Brexit. American Political Science Review 112(2), 201-218.

Cowley P and Stuart M (1997) Sodomy, Slaughter, Sunday Shopping and Seatbelts. Free Votes in the House of Commons, 1979 to 1996. Party Politics 3(1), 119130.

Cutts D et al. (2020) Brexit, the 2019 General Election and the Realignment of British Politics. The Political Quarterly 91(1), 8-23.

Evans G and Menon A (2017) Brexit and British Politics. Cambridge: Polity Press.

Gelman A (2008) Scaling regression inputs by dividing by two standard deviations. Statistics in Medicine 27(15), 2865-73.

Golder M and Stramski J (2010) Ideological Congruence and Electoral Institutions. American Journal of Political Science 54(1), 90-106.

Golder M and Lloyd G (2014) Re-evaluating the relationship between electoral rules and ideological congruence. European Journal of Political Research 53(1), 200212. 
Grande E and Kriesi H (2012) The transformative power of globalization and the structure of political conflict in Western Europe, In Kriesi H, et al. (eds.), Political Conflict in Western Europe. Cambridge: Cambridge University Press, pp. 3-35.

Hanretty C (2017) Areal interpolation and the UK's referendum on EU membership. Journal of Elections, Public Opinion and Parties 27(4), 466-483.

Hanretty C et al. (2017) Dyadic Representation in a Westminster System. Legislative Studies Quarterly 42(2), 235-267.

Hayton R (2021) Brexit and party change: The Conservatives and Labour at Westminster. International Political Science Review doi: $10.1177 / 01925121211003787$.

Heppell T et al. (2017) The United Kingdom Referendum on European Union Membership: The Voting of Conservative Parliamentarians. JCMS: Journal of Common Market Studies 55(4), 762-778.

Hix S and Noury A (2015) Government-Opposition or Left-Right? The Institutional Determinants of Voting in Legislatures. Political Science Research and Methods 4(2), 249-273.

Hobolt SB (2016) The Brexit vote: a divided nation, a divided continent. Journal of European Public Policy 23(9), 1259-1277.

Hobolt SB et al. (2020) Policy Preferences and Policy Legitimacy After Referendums: Evidence from the Brexit Negotiations. Political Behavior doi: 10.1007/s11109020-09639-w.

Intal C and Yasseri T (2019) 'Dissent and Rebellion in the House of Commons: A Social Network Analysis of Brexit-Related Divisions in the 57th Parliament', (doi: 1908.08859v1).

Johnston R et al. (2018) Geographies of Brexit and its aftermath: voting in England at the 2016 referendum and the 2017 general election. Space and Polity 22(2), 162187.

Lynch P and Whitaker R (2017) All Brexiteers now? Brexit, the Conservatives and party change. British Politics 13(1), 31-47.

Lynch P et al. (2019) Brexit and the UK parliament: Challenges and Opportunities, In Christiansen T and Fromage D (eds.), Brexit and democracy. The Role of Parliaments in the Uk and the European Union. Basingstoke: Palgrave, pp. 5179.

McLean I et al. (2003) None of the Above: The UK House of Commons Votes on Reforming the House of Lords, February 2003. The Political Quarterly 74(3), 298-310.

Moore L (2018) Policy, Office and Votes: Conservative MPs and the Brexit Referendum. Parliamentary Affairs 71(1), 1-27.

Prosser C (2021) The end of the EU affair: the UK general election of 2019. West European Politics 44(2), 450-461.

Riker WH (1961) Voting and the Summation of Preferences: An Interpretive Bibliographical Review of Selected Developments During the Last Decade. American Political Science Review 55, 900-911.

Strøm K (2006) Parliamentary Democracy and Delegation, In Strøm K, et al. (eds.), Delegation and Accountability in Parliamentary Democracies. Oxford: Oxford University Press, pp. 55-106.

Thompson H (2021) The European Geopolitical Space and the Long Path to Brexit. Government and Opposition doi: 10.1017/gov.2021.1. 
Thomson L and Yong B (2019) What Do We Mean by Parliamentary Scrutiny of Brexit? A View from the House of Commons, In Christiansen T and Fromage D (eds.), Brexit and democracy. The Role of Parliaments in the Uk and the European Union. Basingstoke: Palgrave, pp. 29-49.

Trumm S et al. (2020) The 2016 EU Referendum: Explaining Support for Brexit Among Would-Be British MPs. Political Studies 68(4), 819-836.

Umit R and Auel K (2020) Divergent preferences and legislative speeches on Brexit. Journal of Elections, Public Opinion and Parties 30(2), 202-220.

Vasilopoulou S and Talving L (2018) British public opinion on Brexit: controversies and contradictions. European Political Science 18(1), 134-142.

Watson M (2017) Brexit, the left behind and the let down: the political abstraction of 'the economy' and the UK's EU referendum. British Politics 13(1), 17-30.

Wheatley J (2019) The Changing Shape of Politics. Rethinking Left and Right in a New Britain. London: Palgrave. 